\title{
Reconstructing Pure Land Buddhist Architecture in Ancient East Asia
}

\author{
Young-Jae Kim
}

check for updates

Citation: Kim, Young-Jae. 2021. Reconstructing Pure Land Buddhist Architecture in Ancient East Asia. Religions 12: 764. https://doi.org/ $10.3390 /$ rel12090764

Academic Editor: Shuishan Yu

Received: 10 August 2021

Accepted: 2 September 2021

Published: 14 September 2021

Publisher's Note: MDPI stays neutral with regard to jurisdictional claims in published maps and institutional affiliations.

Copyright: (C) 2021 by the author. Licensee MDPI, Basel, Switzerland. This article is an open access article distributed under the terms and conditions of the Creative Commons Attribution (CC BY) license (https:// creativecommons.org/licenses/by/ $4.0 /)$.
The Department of Heritage Conservation and Restoration, Korea National University of Cultural Heritage Buyeo 33115, Korea; kyjandy@nuch.ac.kr

\begin{abstract}
Pure land comes from the Indian term "sukha," which means welfare and happiness. However, in East Asia, Buddhism has been associated with the theological concepts of the immortal realm in the bond of death and afterlife. This study reviews detailed conception of Pure Land architecture in Sanskrit literature, as well as Buddhist sutras. The thesis notes that the conceptual explanation of Pure Land architecture, which describes the real world, becomes more concrete over time. Such detailed expression is revealed through the depiction of the transformation tableau. Hence, through Pure Land architecture situated on Earth, this research shows that Buddhist monks and laypeople hope for their own happy and wealthy settlement in the Pure Land. The building's expression of transformation tableaux influences the layout and shape of Buddhist temples built in the mundane real world at that time. Moreover, this study notes that Bulguksa Monastery is a cumulative product of U-shaped central-axis arrangements with courtyards, terraced platforms, high-rise pavilions, and lotus ponds, plus an integrated synthesis of religious behaviors by votaries as a system of rituals. Further, it merges pre-Buddhist practices and other Buddhist subdivisions' notions with Hwaeom thought, in comparison with Hojoji and Byodoin Temples that follow the Pure Land tradition.
\end{abstract}

Keywords: pure land (sukhavati); Bulguksa Monastery; Buddhist grottoes; transformation tableaux; immoral world

\section{Introduction}

In East Asia, the Buddhist Pure Land, which is derived from the Indian term sukha, was intimately concerned with the theological concept of the immortal realm in the bond of death and afterlife. Immortal Taoist paradises and Buddhist Pure Lands have something in common and interact and communicate with each other. In Pure Land tradition, a combination of rituals, such as visualization and meditation, can bring an individual one step closer to the richness of the Pure Land. (Corless 1982; Pas 1987; Xiao 1989; Wu 1992a).

The concept of Pure Land architecture, which is intended to express the real world, became more concrete over time. Such detailed illustration was revealed through the depiction of the transformation tableaux and pictorial spatial representations, which connote narrative moments, events, and places. (Mair 1986; Wu 1992b) The architecture of Maijishan, Xiangtangshan, and Dunhuang Cave Temples depict the Pure Land in the real world. The Buddha sitting at the center of the bodhisattvas, in terraces over a lotus pond, represents a happy configuration. The horseshoe-shaped architectural complex of grand buildings are copies of palaces or great monasteries in the imperial capital. Pure Land consciousness is exhibited as buildings and objects that represent the horizontal courts and ponds of Buddhist monasteries in the real world.

This thesis highlights the detailed conception of Pure Land architecture in understanding Sanskrit literature and the Buddhist sutras, ${ }^{1}$ and emphasizes the contribution of Buddhist murals in providing ritual prototypes over time. It also focuses on the roles of symbolic fabrics in monasteries such as Bulguksa, Hojoji, and Byodoin, which represent Pure Land architecture on Earth. In particular, the scattered Bulguksa buildings incorporate 
elevated flat stone platforms and a lotus-filled pool surrounded by various trees. This study suggests that such an architectural composition stemmed from the Pure Land scriptures and transformation tableaux as a system of rituals that enabled devotees to search for their own happy and comfortable settlement therein.

\section{Conceptualization of the Pure Land in Buddhist Literature}

The sahaloka (real world) is the Pure Land. ${ }^{2}$ The saha world is considered as assorted, ornamented or unornamented, and pure or impure, because all beings remain tied by the laws of causation and are subject to transmigration. However, the saha world can be the land of transformation in the presence of the Buddha, and beings are transformed there within their dwellings. Therefore, the preaching Buddha and stupas (or cetiyas) in the Pure Land allude to the transformative power of the Buddha in purifying this land and preparing people for rebirth (Wong 1998, pp. 67-68; 2008; Tsukamoto 1986, Tsukamoto 1996-1998). Parallel to the nature of stupas and cetiyas, temples with Buddha halls/Buddha pagodas in East Asia were re-designed as new models of Buddhist temples in the real world. They were renamed as a specific building type to depict the Pure Land. Indeed, Pure Land architecture carries the meaning of sacred places or shrines associated with events or stories of meditation, enlightenment, and nirvana. In particular, the term "sukha," notably means welfare and happiness (or comfort). The sukha was discovered in inscriptions in the majority of Buddhist sites, such as Nagarjunakonda, Mathura, and Amaravati (Vogel 1929-1930; Tsukamoto 1996-1998). ${ }^{3}$ The inscriptions indicated below are among them.

For the attainment of welfare and happiness in both the worlds (ubhaya-lokahita-sukha) and of Nirvana has erected this stone pillar (skambha), in the sixth year of (the reign of) King Siri-Virapurisadata, and the sixth fortnight of the rainy season, the 10th day. From the inscriptions of Nagarjunakonda Sites 1, 5, and $43 .{ }^{4}$ (Vogel 1929-1930; Tsukamoto 1996-1998; Macdonell 1929; Apte 1957-1959)

Around Buddhists remain near Nagarjunakonda and Amaravati, it is not unusual to find inscriptions like "ubhaya-loka-hita-sukha" engraved on most ayaka-pillars. Most donor inscriptions on monuments sited by intellectual monastics at primary pilgrimage venues end with the phrase" for the welfare and happiness of all beings." In addition, Nagarjuna, who probably lived in the Purvasaila, Aparasaila, and Caityaka monasteries during the time he wrote the Ratnavali (Walser 2005, pp. 87-88), indicated that we could obtain the "welfare and happiness of all beings" and become great men through a new devotion toward Buddhist images, stupas, and shrines. ${ }^{5}$

Most early sutras in Chinese were published before 220CE, interpreting the "Sukhavati (happy land)" in transliteration as the “xumoti 須摩提 or 須訶摩提” (Fujita 1970, pp. 141-61; Iwamoto 1978, pp. 57-79). The Banzou sanmei sutra mentions that in the seat of the xumoti, bodhisattvas sat in the center and recited sutras, and all adherents longed for Amitabha. (Taisho 13, no. 418). In the proper sense, the Sukhavati was not a heaven at all; rather, it could be found anywhere on Earth because the sutras said that in xumoti, wealthy merchants had high social standing and possessed a great deal of gold and jewels (Fujita 1970, p. 256; Nakamura 1975, p. 205). In addition, the emergence of the "xumoti" area was closely associated with the occurrence of Amitabha Buddha. ${ }^{6}$ In contrast, the Zoroastrian religion was established through the impact of the worship of the sun god because the Pure Land has been described as a "paradise of infinite light" in the Zoroastrian scripture "Avesta" (Tsukamoto 1986, pp. 394-95; Nakamura 1975, p. 204). Paradise literally means enclosure. It designates a demarcated, finite, and protected space from the openness of chao (Pyyhtinen 2014; Kim 2018). 
From 220 CE to the early seventh century, a Chinese transliteration of the "Sukhavati" was beginning to be known as the "anle," which implied "comfort and happiness." It was substituted for the "jile" (extreme happiness) and "jingtu,"(pure land), respectively, in the translation of the monk Kumarajiva in the fifth century. It does not refer to Amitabha's land, but rather regards it as purifying the Buddha land. ${ }^{7}$ A significant point in the changes in translation regarding the "Sukhavati" is that the Chinese transliteration gradually adopts the definition of the "land of welfare and happiness." ${ }^{8}$ The correct understanding of the meaning of Pure Land was very significant because such a deliberate attempt helped augment Buddhist authenticity and its mystical power by returning to the original term ostensibly connected with the homeland of Buddhism (Mizuno and Toshio 1941). This is a good representation of the acceptance of foreign culture, and adaptation of important ideas from East Asian countries.

\section{Embodiment of the Buddhist Pure Land in Transformation Tableaux}

In East Asian culture, the understanding of the Pure Land World was well-expressed in huge depictions, called the "bianxiang (transformation tableau)," with rich content and complex compositions at cave temples. They reinterpreted Buddhist stories from the jiangjing (sutra oratory) and guanxiang (visualization) literature produced for ritual participation. (Mair 1986; Wu 1992a, pp. 55-56; 1992b, pp. 111-12). The Buddhist Pure Land's construction on earth was built in concrete ways by devotees of both editorialization and architecturalization. The constructions appeared in paintings, sculptures, and architecture. The figures were composed of buildings, bridges, platforms, and passageways with balustrades, ponds, and many manifested bodies of bodhisattvas and deities. Such depiction was a very creative method and considered a meritorious deed, especially for monks, such as Huiyuan 慧遠 (334-416) in Sichuan, Shandao 善導 (613-681) in Dunhuang, and Zhiyi 智顗 (538-597) in Jiangnan who provided a guideline for the Pure Land's pictorialization (Sponberg and Hardacre 1988, pp. 94-95; Kitagawa 1988; Hay 1999, p. 240). The appearance of the transformation tableau helps people to be reborn in Amitabha's paradise, which is depicted in the main painting. ${ }^{9}$ Huiyuan's commentary still emphasized meditating to the Buddha, and thus continued the old tradition of visualizing the Amitabha, "guanfo," in the mind, which was probably based on the Pratyupannasamadhi sutra (Zürcher 1959, pp. 180, 223). ${ }^{10}$ However, unlike Huiyuan, his teacher Daoan meditated on Maitreya (Kieschnick 1997, p. 5). ${ }^{11}$ Early Chinese monks were well-known for using the meditation techniques of "bhavana" or "samadhi," which consisted of both the meditative absorption of concentration and contemplation through pictures; through this practice, devotees felt that their inner spaces were broadened when they looked at many buildings through the cultivation of samadhi.

On the contrary, Shandao's commentary differed from the older Visualization Sutra in declaring that laypeople, monks, nobles, and commoners had the chance of rebirth in the western Pure Land (Chappell 1977). He confirmed that successfully visualizing the "sukhavati" was the key to the attainment of both eternal happiness and wealth (Wu 1992a). Shandao's visualization methods were initially influenced by Tanluan (量鸞, 476-542), who proposed an easy path through visualization, and whose view consisted of three forms: the merit of manifestation through visualization of the Pure Land, the Buddha, and the bodhisattvas. Tanluan's representation methods were linked with the Taoist visualization of immortal mountains (Corless 1982, pp. 36-45). Nonetheless, Shandao's role was very important. While Tanluan used visualization meditations in Pure Land rituals, Shandao invented the use of illustration for a visualization based on the 16 meditations in the Amitayurdhyana sutra. As a result, the illustration tool for meditation was further extended to the construction of buildings on Earth (Pas 1987; Taisho 47, no 1959). 


\section{The Immortal Taoist Paradise and the Pure Land in Korean Society}

The Dae Hwaeomjong Bulguksa birojanamunsuboheonbosal chanbyeongseo 大華嚴 宗佛國寺昆盧遮那文殊普賢像灒抹序 consists of an introduction to and eulogy about the Vairocana Buddha on the left wall, and the Samantabhadra and Manjusiri on its left and right sides at the Gwanghakjang Gangsil 光學藏講室 to memorialize the Silla King Heongang (r. 875 886). Queen Gweon, a concubine of the King, offered the images that led to the statement "Heongang was one of the immortals, while his queen was the manifestation of the bodhisattva." When he came down from a silver palace 鶏林, surprisingly, King Heongang came to the land of Gyerim 鶏林 (Rooster's forest), a legendary site of Silla's founding, to govern Geumseong (City of Gold; present Gyeongju) during the Silla period. ${ }^{12}$ Silla society believed that kings came from Taoist heaven and were considered immortal. The merging of rulers and immortals resembled a chakravartin king and an enlightened holy man, because the chakravartin king in the Pali canon is paired with the Buddha as a secular counterpart and conqueror of the universe. ${ }^{13} \mathrm{He}$ protects his destitute subjects (Zürcher 1959, p. 292). The enshrinement of an Asoka statue at the Silla Hwangnyongsa temple in 549 CE, at the instance of King Jinhung (r. 534-576), was implied to reinforce the power and prestige of the Silla kingship, ${ }^{14}$ which was meant to be dedicated to the Buddha, and serve as an allusion to royalty for a ruling world monarch. The political use of Silla Buddhism followed the patterns of the Chinese dynasties of the Northern Wei, Sui, and Tang, in which rulers used Buddhist symbols and ideas, along with Taoism and Confucianism, to support their power.

Silla Buddhism was differentiated from that of Chinese dynasties because the ruling monarch tried to merge the advantages of transcendent immortals, transformative Buddhas, and righteous chakravartin into one frame. ${ }^{15}$ Such acts were not limited to the ruling monarchs, but took place among the aristocrats and other lower ranks. Kim Ji-Seong, a trueborn noble, commissioned the images of both Maitreya and Amitabha to adorn a monastery, named Gamsansa Monastery, in 716. The inscription mentions that Kim studied Taodejing, and served Zhuangzi and Laozi in his philosophical pursuit and accomplishments. ${ }^{16}$ Therefore, pagodas and pavilions are not only an emblem of holy places that signify the Buddha's life stories, but preserve a pavilion for hermits associated with the immortal world. The posthumous settings were a mixture of Taoist dwellings and the Pure Lands (Wright 1948, p. 355; Wu 1992a, p. 135).

\section{Real World Representation of a Pure Land at Bulguksa Monastery}

Bulguksa 佛國寺, meaning a monastery of the Pure Land, was situated at the base of Mt. Toham, a 745-meter high mountain on the southeastern edge of Gyeongju. It was founded in the first year (742) or the 10th year (752) of King Gyeongdeok's reign (r. 742-765, 景德王) as one typical model among medieval monasteries, with a hall and two pagodas. ${ }^{17}$ The late historical records of Korea state that the monastery compound was built by Kim Daeseong, a prime minister of Silla. Kim Daeseong carried out the construction of Bulguksa on the western hillside of Mt. Toham, and Seokbulsa on the western hillside of the same mountain, in honor of his parents in their past and present existence. ${ }^{18}$

Bulguksa has a very impressive plan that represents both the Sakyamuni and Amitabha Pure Lands. The first sphere consists of two elevated Buddha pagodas placed in front of the Daeungjeon (the Great Hero Hall) with five (front facade) by four bays (side). The central bay is much wider than the other bays, It lies on a central north-south axis that devotees enter through the center of Baekwungyo (White Cloud) and Chungwungyo (Blue Cloud) Bridges, plus upper and lower grand terraced platforms, Jahamun Middle Gate (Purple Mist Gate), Daeungjeon Hall, and Museoljeon Lecture Hall (Non-word). This courtyard has two stone pagodas, which were renamed during the reconstruction work of the Joseon period when they came to be called Seokgatap Pagoda (West) for Tathagatha Sakyamuni and Dabotap Pagoda (East) for the abode of Tathagata Prabutaratna, according to the Sadarmapundarika (Lotus) sutra (Taisho 9 no 262). They were originally called the Seoseoktap (West) and Mugujeonggwangtap (Endless Untainted Light or Dongtap (East)) 
Pagodas according to epigraphical evidence recently restored from four historical records in fragments, which were associated with the restoration campaigns of the pagodas in the Goryeo era (918-1392). ${ }^{19}$

Conversely, another courtyard forms the realm of Amitabha Buddha, which is situated in the western precinct of the Daeungjeon Hall. The ambit has only one building, the Geukrakjeon (Extreme Bliss Hall). Votaries ascend into the present Pure Land utilizing two finely carved stone bridges, the Chilbogyo (Seven-Gems) and Yeonhwagyo (Lotus) Bridges with open terraced platforms, and then enter through the Anyangmun Gate (Comfort and Happiness). The "anyang" means the world of "sukhavati." These "chilbo" and "yeonhwa" are direct references to the sukhavati Pure Land because all sukhavati worlds subsumed the lotus and seven treasures, as referred to in Pure Land sutras.

The tall pavilions, Beomyeongnu (Ugyeongru) Pavilion and Jwagyeongnu Pavilion, were established on both end corners from the front façade, while the "Gupum Yeonji," meaning the lotus pond of the nine ranks, is an oval lotus pond situated below the Cheongwungyo and Baekwungyo Bridges (Figures 1 and 2).

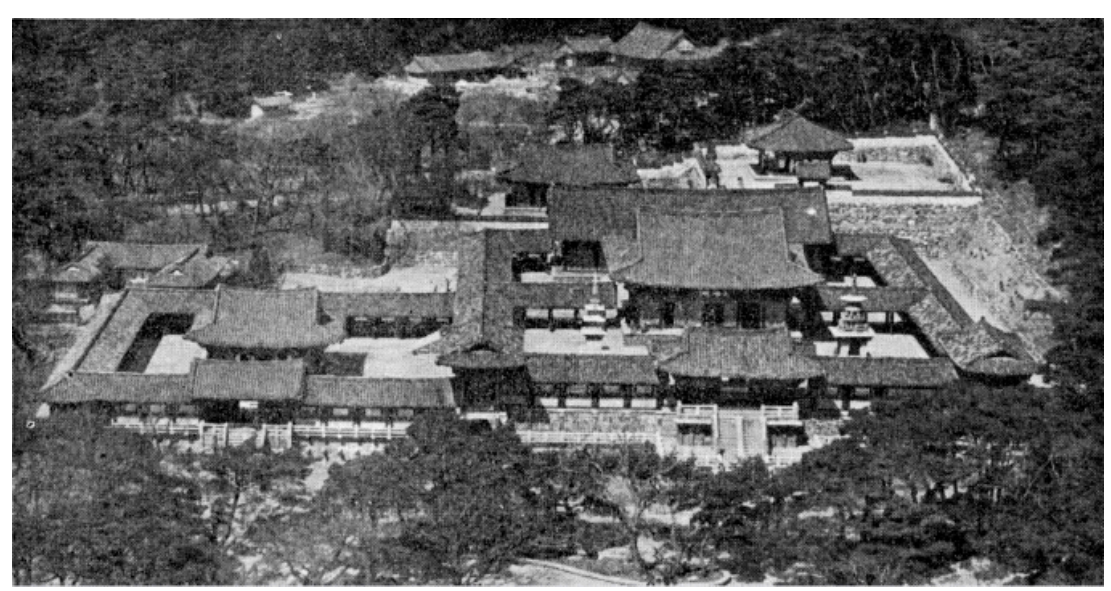

Figure 1. Whole view of Bulguksa after the 1969-73 restoration work (source: Dongailbo, 16 March 1976).

This is related to Hwaeom's idea that several Pure Land concepts coexist and fuse according to the concept of dependent origination, in order to meet realistic demands. These efforts resulted in the construction of great temples to create a unifying plan for harmonizing various doctrines and performing rituals for matching the doctrines. One of these was the Bulguksa. Beopgyedogi chongsurok 法界圖記叢隨錄 records that Kim Daeseong was taught by Pyohun in Hwangboksa Temple (Beopgyedogi Chongsurok 1254), and thus knew the method for practicing the Hwaeomsambonjeong 華嚴三本定 (the three essential concentrations of Hwaeom Samadhi) by realizing the three fundamentals of the undisturbed mind. The highest ideal world in Avatamsaka thought is called the Lotus World, a world of enlightenment. Through all religious behaviors executed within the buildings at Bulguksa Temple as a ritual machine, all distinctions disappear and a state of perfect harmony among all differences is achieved. That is, Minister Kim tried to create an integrated religious tool that could accommodate the various ideologies of Silla society by combining Taoist practices for posthumous rebirth with royalty-and-filial-piety-oriented Confucianism.

Based on this integrated Avatamsaka thought, the visible Sakyamuni Pure Land was identical to the utopian Lotus World, placing Sakyamuni Buddha in a position above the Amitabha Buddha to emphasize the fundamental position of Buddhism. Bulguksa's architecture displays this teaching method with extreme clarity. 


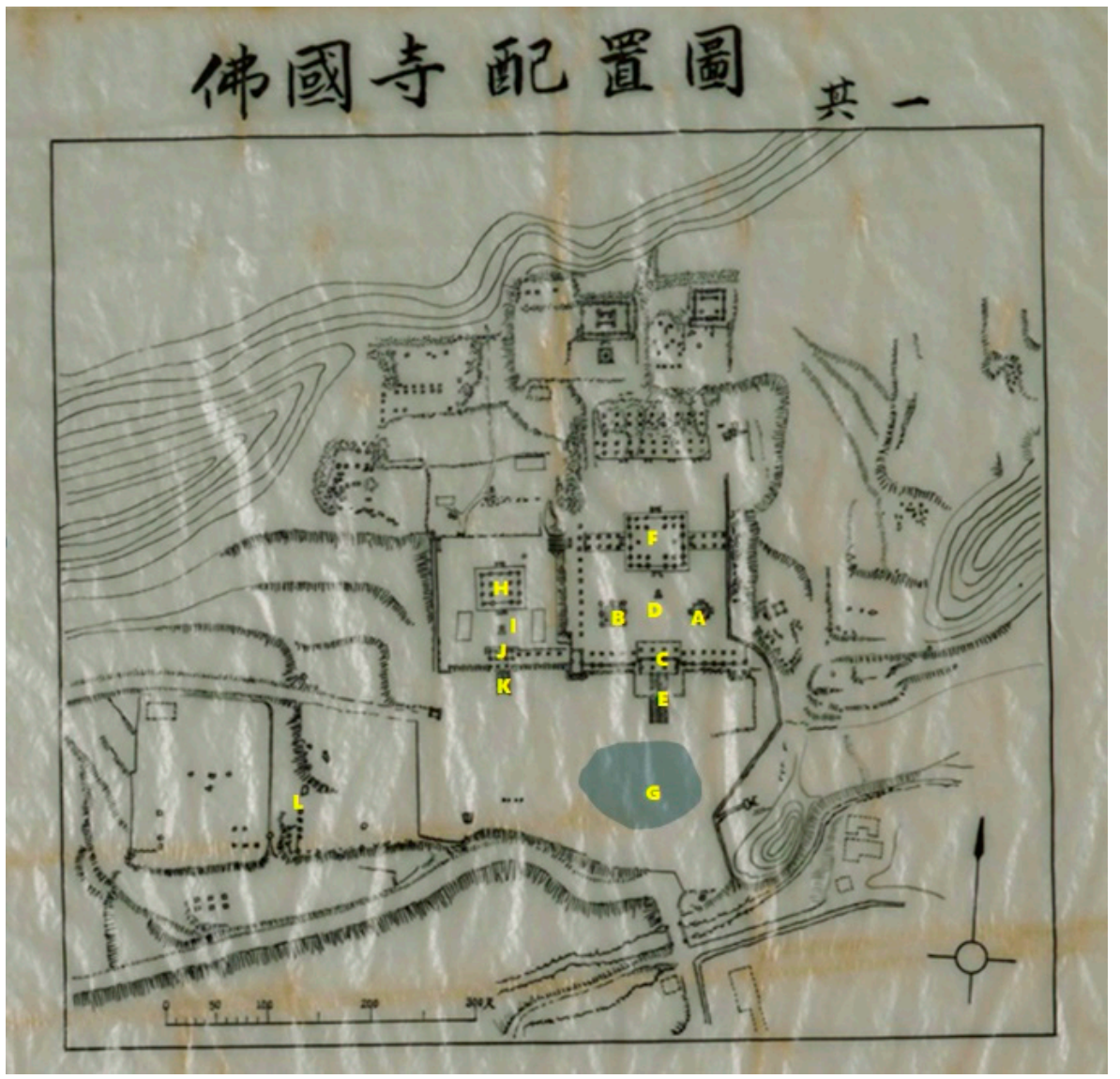

Figure 2. Lotus Pool (Nine Ranks for Rebirth) and Building Remains after 1924 (Gukga girokwon). A: East Pagoda (Dabotap), B: West Pagoda (Seokgatap), C: Gate (Jahamun), D: Worship Stone (Bongnodae), E: Bridges and Platforms (Cheogungyo and Baekun Bridges), F: Mahavira Hall (Daeungjeon Hall), G: Lotus Pool (Pond), H: Amitabha Hall (Geukrakjeon Hall), I: Worship Stone (Bongnodae), J: Gate (Anyangmun) K: Bridges and Platforms (Yeonhwa and Chilbo Bridges), L: Anonymous Building Remains.

\subsection{Common Views in Pure Land Scriptures}

Primary sutras related to Pure Land were produced from the second century onward. The Kushan monk Lokaraksa translated the Wuliang qingjing pingdengjue jing 無量清淨平 等覺經 (Taisho 12, no 361) in the latter half of the second century. A little later, the Kushan Zhi Qian 支謙, a pupil of Lokaraksa, translated the Foshuo amituo sanye sanfosalou guodu rendao jing 佛説阿彌陀三耶三佛薩樓佛檀過度人道經 (Taisho 12, no 362) in the second quarter of the third century. Samghavarman 康僧鎧 translated the Larger Sukhavati vyuha sutra 佛説無量壽經 (Taisho 12, no 360) in 252, and Kumarajiva 鳩摩羅什 translated the Smaller Sukhavati vyuha sutra 佛説阿彌陀經 (Taisho 12, no 366) in around the 400s. Jiangliangyeshe 畺良耶舍 translated the Amitayurdhyana sutra 觀無量壽經 (Taisho 12, no 365 ) in the fifth century. These sutras share a universal conception that persons who stayed in defiled seeds can go into rebirth before gaining salvation in the Pure Land when they accumulate virtues through alms activities.

Among them, the Wuliang qingiing pingdengjue jing and Foshuo amituo jing mentioned a hermitage called the "shezai 舍宅." The Amitabha Buddha was placed inside the lecture hall and hermitage. The concrete expression of the Pure Land appeared in two sutras: the Larger Sukhavati vyuha sutra and the Smaller Sukhavati vyuha sutra. The former records a discourse offered by Bhagavat (Buddha) on Vulture's Peak near Rajagrha in response to his disciple Ananda, "The lecture halls, hermitages, palaces, tall towers, and watchtowers were built on the land. They were adorned by seven jewels with natural consequences, and therefore, multifold pearls that can glow in the dark were covered" 
(Taisho 12 no 360). The depictions of buildings on the Pure Land in the Sanskrit version ${ }^{20}$ mentioned "gardens, palaces, and pavilions on the land."

The latter, the Smaller Sukhavati vyuha sutra, depicts "lakes, stairs, and pavilions" adorned with the seven jewels made of gold, silver, beryl, and crystal. The Buddha tells Shariputra, "In the land, sukhavati (there are seven rows of balustrades, seven rows of fine nets, and seven rows of arrayed trees; they are all four gems and surround and enclose (the land). The lake bases are strewn with golden sand, and the stairs on the four sides are made of gold, silver, beryl, and crystal. On the land, there are multi-storied pavilions and galleries embellished with gold, silver, beryl, crystal, white coral, red pearl, and diamond" (Taisho 12, no 366). In contrast, the Amitayurdhyana sutra explains sixteen visualization meditations. The beginning of the first visualization is a meditation on the sun. The second envisions that the western region is flooded by pure water, which turns into ice, then into beryl. The flat ground of the Pure Land is made of beryl and is supported by columns made of various jewels. The third and fourth visualizations focus on the lapis lazuli Earth and jeweled trees. The fifth and sixth contemplate the water of eight excellent qualities and the myriad jeweled pavilions on the Pure Land. The seventh contemplates the jeweled lotus throne of Amitabha (Taisho 12, no 365).

It is worth noting that the pavilions (louge), including balustrades and ponds enriched with gold, silver, beryl, crystal, white coral, red pearl, and diamond have been commonly and persistently used to adorn buildings. Palaces, lakes, stairs, gardens, and pavilions in the Pure Land were compared in all versions of the scriptures. This suggests a link with Taoist tradition and the building types popularly used at that time in Western areas (Corless 1982, pp. 36-45).

\subsection{Architectural Characteristics of Transformation Tableaux}

The synthesis of tall pavilions and ponds began to appear in the transformation tableaux in the early sixth century. This combination started in the early sixth century across East Asia, and took place at the following sites: West Pure Land at the Maijishan Cave 127 (Gansu) in the early sixth century (Figure 3), Pure Land depiction with the secular landscape of Wanfosi Stele (Chengdu) of the early sixth century in the Liang era (Figure 4), and the bas-relief of Amitabha Pure Land found in the southern Xiangtangshan Caves 1 and 2 (Hebei) of the sixth century during the Northern Qi period (Katsuki 1992; Li 2007) (Figures 5 and 6).

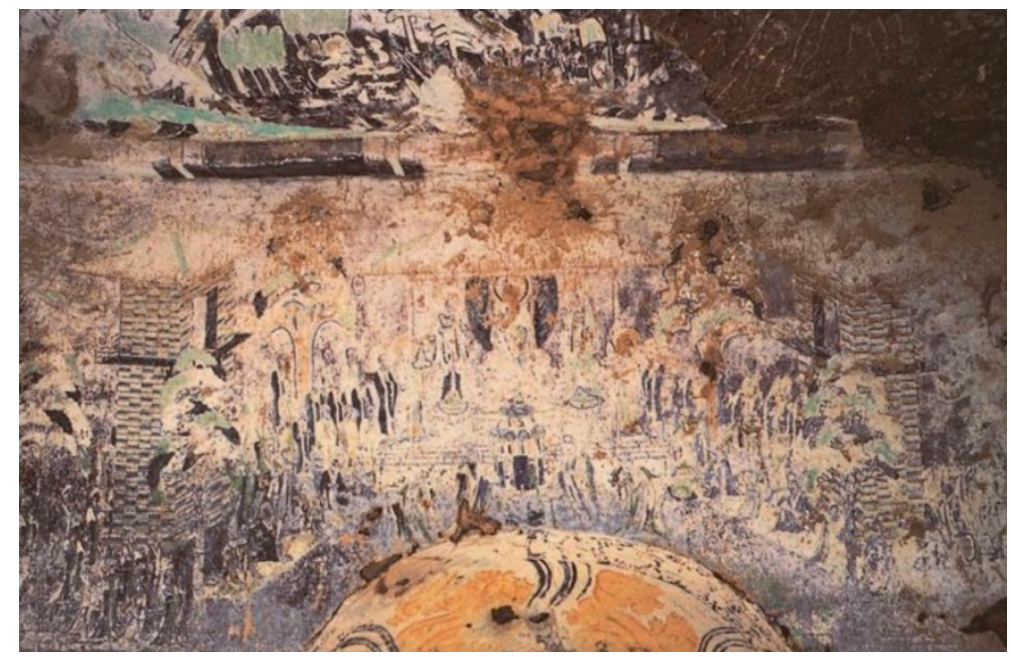

Figure 3. West Pure Land, Maijishan 127, early-sixth-century Gansu. 


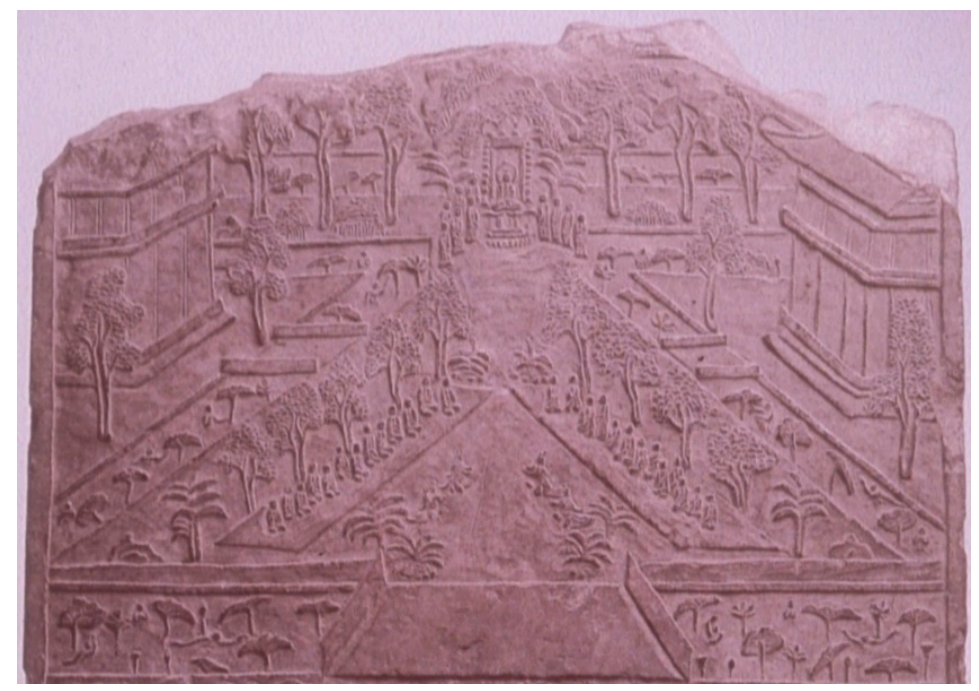

Figure 4. Pure Land depiction with secular landscape. The reverse of Wanfosi Stele, early-sixthcentury Liang.

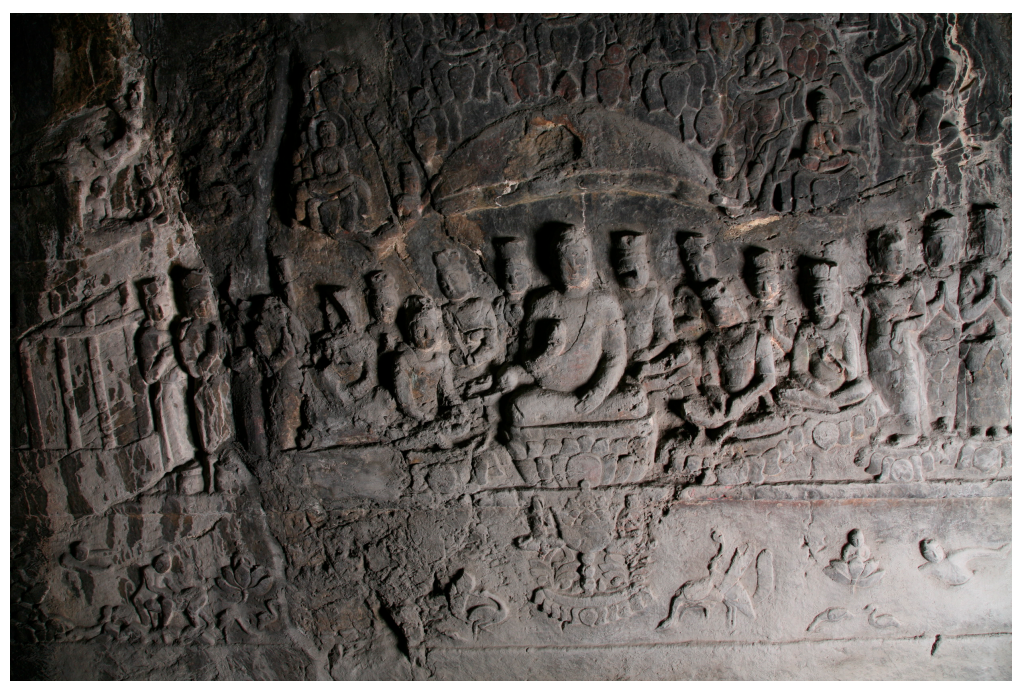

Figure 5. West Pure Land of Amitabha, Xiangtangshan Cave 1, sixth-century Northern Qi (Freer Gallery of Art).

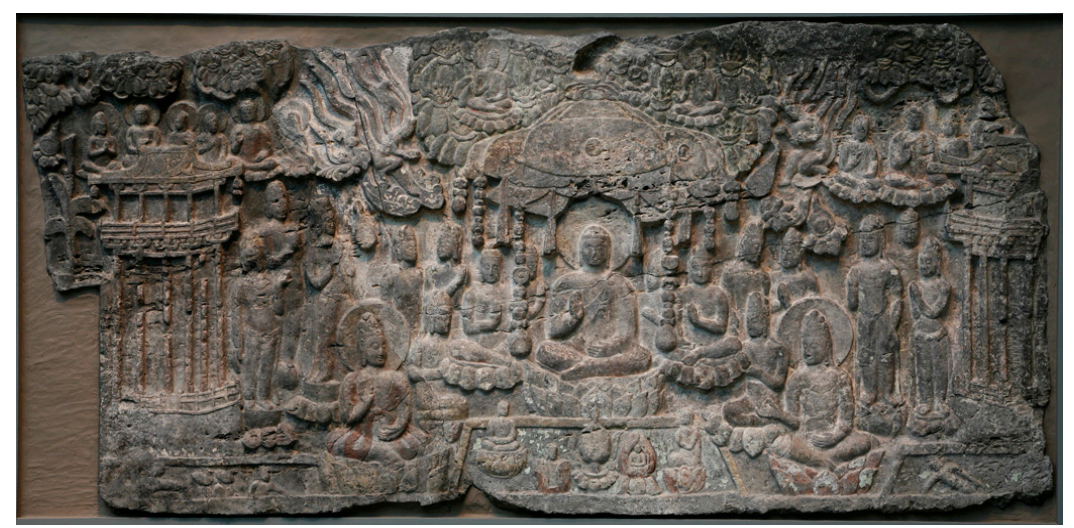

Figure 6. West Pure Land of Amitabha, Xiangtangshan Cave 2, sixth-century Northern Qi (Freer Gallery of Art). 
The early portrayals of the Pure Land have consisted since the fifth century of two elevated towers or halls on both sides and the Buddha figure flanked by attendants. The pair of towers enhance the centering of the Buddha figure flanked by bodhisattvas, together with many attendants, musicians, apsaras, and reborn beings. In particular, the two basreliefs of the Xiangtangshan Cave illustrated paired timber buildings standing on the flat substructure under bracketing sets above columns, with an elevated floor on pile constructions (Figures 5 and 6).

Dunhuang Cave 393 during the Sui period (581-618) presented different patterns. The Buddha figure is naturally located at the center of the painting's composition without any buildings, but a lotus pool is found beneath it. There are beings at the moment of rebirth in the pool, attendant figures, and flying apsaras on both sides (Figure 7). Pure Land's transformation tableaux started to subsume buildings in these illustrations from the Tang period onward, and the number of buildings gradually increased with the appearance of different types. Remarkable development appeared in the following works: Dunhuang Caves 220, 71, 321, 322, 329, 334, 335, 217, and Maijishan Cave 5, all constructed during the early Tang period (618-712). ${ }^{21}$

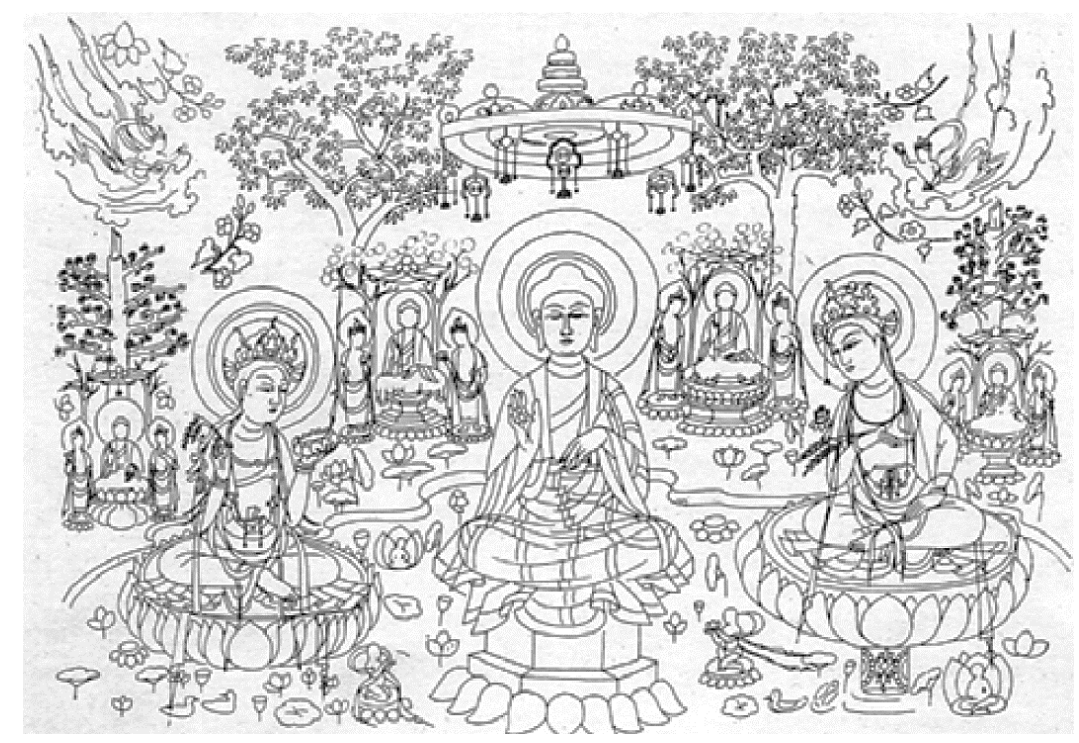

Figure 7. West Pure Land, Dunhuang Cave 393, Sui.

Among these, the early Tang cave 220 describes a simple great platform with balustrades made of seven jewels, and a lotus pool in which many reborn beings presided. The flat platform where the Amitabha triads stand appears to be floating on the water's surface because the mural fills the wall of the cave. The paired two-story pavilions flank a central hall on both sides, along with covered galleries. Amitabha triads in front of the central hall were placed on a level platform, accompanied by many bodhisattvas and attendants. From Dunhuang Cave 220 onward, the tableaux tended to grow more sophisticated, and the number of buildings gradually increased with the emergence of different types (Figure 8). 


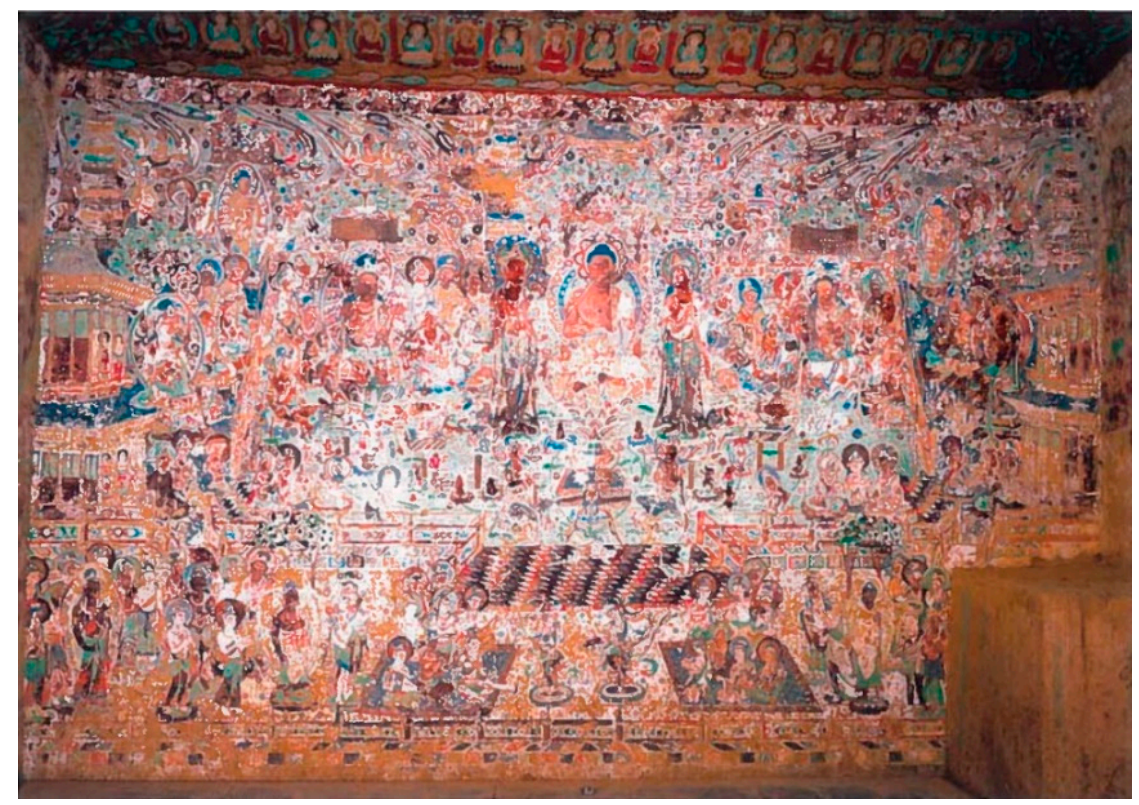

Figure 8. Western Pure Land, South Wall, Dunhuang Cave 220, Early Tang (Xiao 1989).

The West Pure Land of the Amitayurdhyana sutra on the north wall of Cave 217 is representative of all transitions during the high-Tang period. All figures in the composition, including architectural elements, are confined to the front of the rear edge of the lotus pool. Many buildings of varying forms are placed on level ground to the rear of the jeweled pool in front of which the Buddha and attendants are placed. The buildings are divided into two types: individual buildings, including a central front hall and four pairs of tall towers; and a rear building complex consisting of a central hall of three bays square with a hip-gable roof, flanked by twin-wing roofed corridors on both sides (Figure 9).

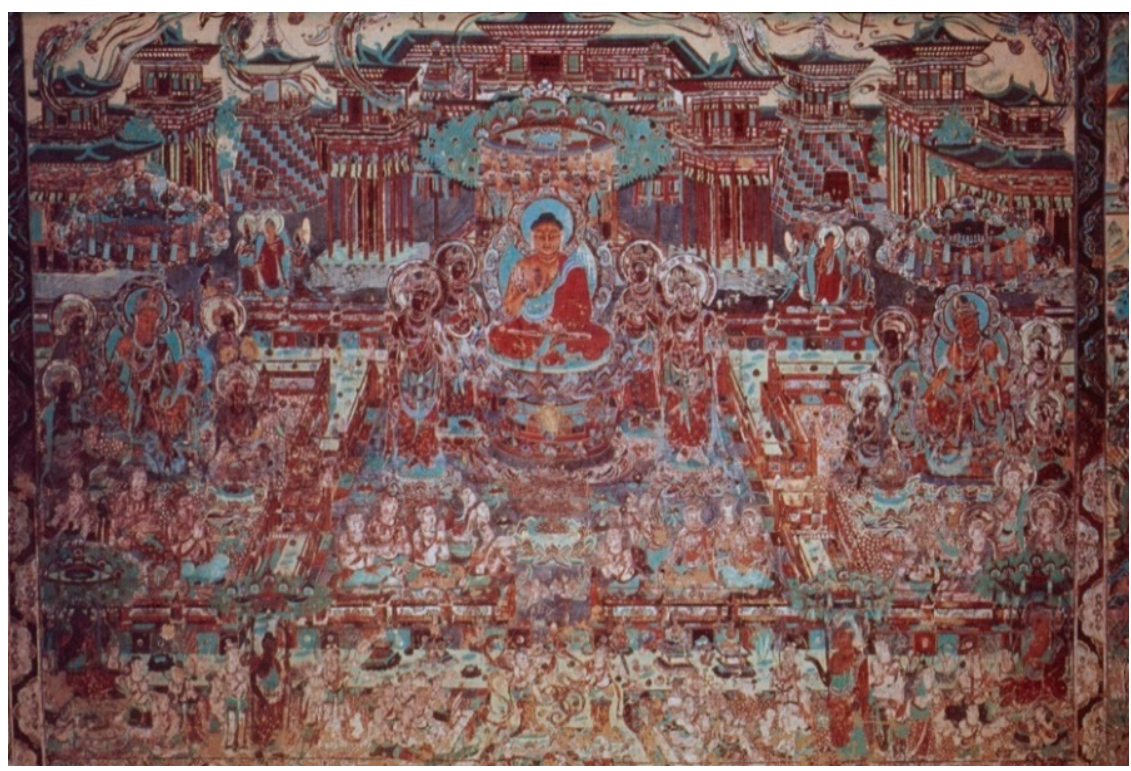

Figure 9. West Pure Land, northern wall, Dunhuang Cave 217, High Tang (Xiao 1989).

The high-rise pavilions called the "louge 樓閣" were built on the left and right. The paired louge buildings are attached to covered galleries to connect the main hall and have different base storeys. The first is made of decorated bricks that prop up a level masonry platform with balconies, and the other is made of timber columns that support level platforms with banisters surmounted by bracket systems. The "Shigong 釋宮" of the 
Erya 爾雅 defines the former as the lou building, narrow and curvedly decorated (Xu 1987, p. 175). The Shuowen jiezi 説文解字 defines the lou building as one with multiple storeys, while the ge building has a substructure system (pingzuo) that holds up the level platform on which housing complexes are placed. The two lou buildings have a pole resembling the chattrayashti or chattravali 相輪 (a vertical shaft that protrudes from the top of a pagoda) on top of each pyramidal roof, while the two ge buildings have a pair of chiwei 註䲩 (owl headed fishtail) on each hip-gable roof with a double row of rafters, which functions as a bell tower with window panel that suggests a belfry and a sutra repository.

Significant changes appeared in the high-Tang cave 172 (Figure 10). To begin with, the central three buildings were grouped on the same platform, further emphasizing them as the center of the architectural composition. The central building at the very front is a fivebay square with a hip-gable roof, and the central bay of the building is much wider than the other bays. The number of buildings along the central axis multiplies, and the figure of the Buddha simultaneously diminishes in scale. This indicates the growing prominence of architectural depiction from the high Tang period onward.

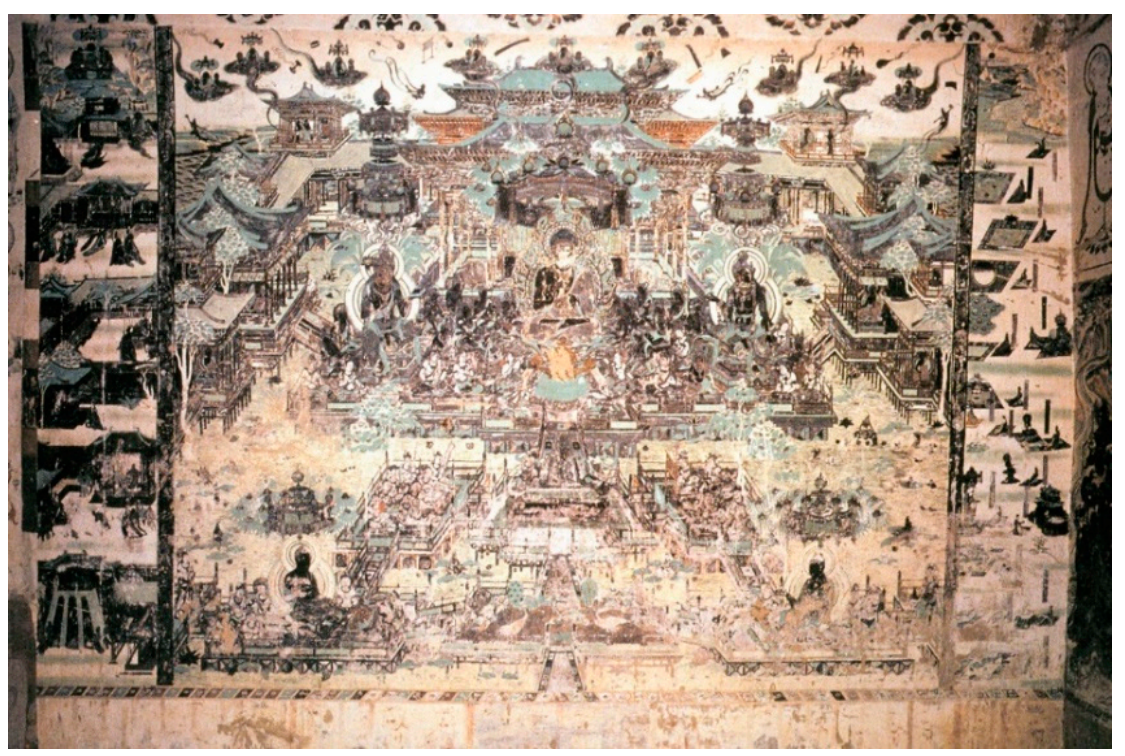

Figure 10. Dunhuang Cave 172: Amitayurdhyana Sutra, south wall, High-Tang (Xiao 1989).

Monastic buildings in the upper half of the illustration correspond closely with the scattered platforms floating on the surface of the lotus pool in the lower half of the mural. From the central line between great platforms with a pond and monastic buildings, and the lotus dais on which the Buddha is placed in front of the main hall with five bays, a one-point perspective was employed. This sense of perspective enables the participants to concentrate on the cultivation of visualization meditation. The cults enable the audience to improve their sense of awe toward the Pure Land. The application of the elevated vantage point in the illustration indicates that the Pure Land was far away from the secular world. Moreover, the well-organized spatial depth in the central group of buildings embraces the votaries in the representation of the paradisiac atmosphere with familiar earthly architectural elements. Thus, this visualization could allow the audience to participate in the bliss of Pure Land in the present world and be quite certain of the possibility of rebirth in the future (Ho 1995, p. 31; Wu 1992a, p. 52).

The building placement in Caves 220, 217, and 172 resembles the main realm of Bulguksa built above the multi-story platforms, as well as the Hoodo of Byodoin sponsored by the Fujiwara family. It is remarkable that high-rise pavilions stand on flat ground surmounted by wooden supports or stone elevated platforms placed along the right and left sides in the transformation tableaux. The elevated towers, flanking the main realm in the center, serve as dwellings for transcendent beings and immortals. Subsidiary buildings 
on the right and left of the primary buildings in the middle are linked with each other through roofed passageways.

\section{Construction of Pure Land Architecture: Bulguksa Monastery and Its Rituals vs. Hojoji and Byodoin Monasteries}

The emphasis on open flat platforms and the central hall in the illustration demonstrates a liturgical space representing an increasing share for the entire pure land cult. Therefore, Buddhas, bodhisattvas, heavenly beings, voice-hearers, celestial musicians, and sentient beings not only gathered to dance or play music, but all beings gathered to hear and worship the preaching Buddha. The buildings are connected by stairs, flat bridges, and arched bridges. The pathways between platforms and halls denote the paths followed by the rituals. The flat stone platform played an important role in intimately linking ceremonial buildings and places.

The representation of the Pure Land in the transformation tableaux reflected not an idealized world, but a real one, which appears in pure land monastic complexes, such as Bulguksa Hojoji and Byodoin Monasteries. Of these, Bulguksa Temple provides a prototype of Pure Land architecture because the temple resembles the Pure Land composition in the transformation tableaux. The temple has a main hall with five bays, two elevated towers flanking the main hall on both sides along roofed corridors, western and eastern Buddha pagodas, a lecture hall behind the main hall, a worship stone, and a stone lamp in the middle between the middle gate and main hall, a flight of stairs, arched stone bridges with balustrades, a middle gate, and multi-storyed elevated platforms with banisters, and a lotus pool. The main stone platforms consisted of Baekungyo (blue cloud) and Cheongungyo (white cloud) bridges, which form a long stairway before reaching the Jahamun Gate. The pure-land constructions mounted on the grand platform represent the narratives of the Amitayurdhyana and the Larger Sukhavati vyuha sutras, ${ }^{22}$ in which the main realm is connected with roofed corridors via multi-story platforms (Figure 11).

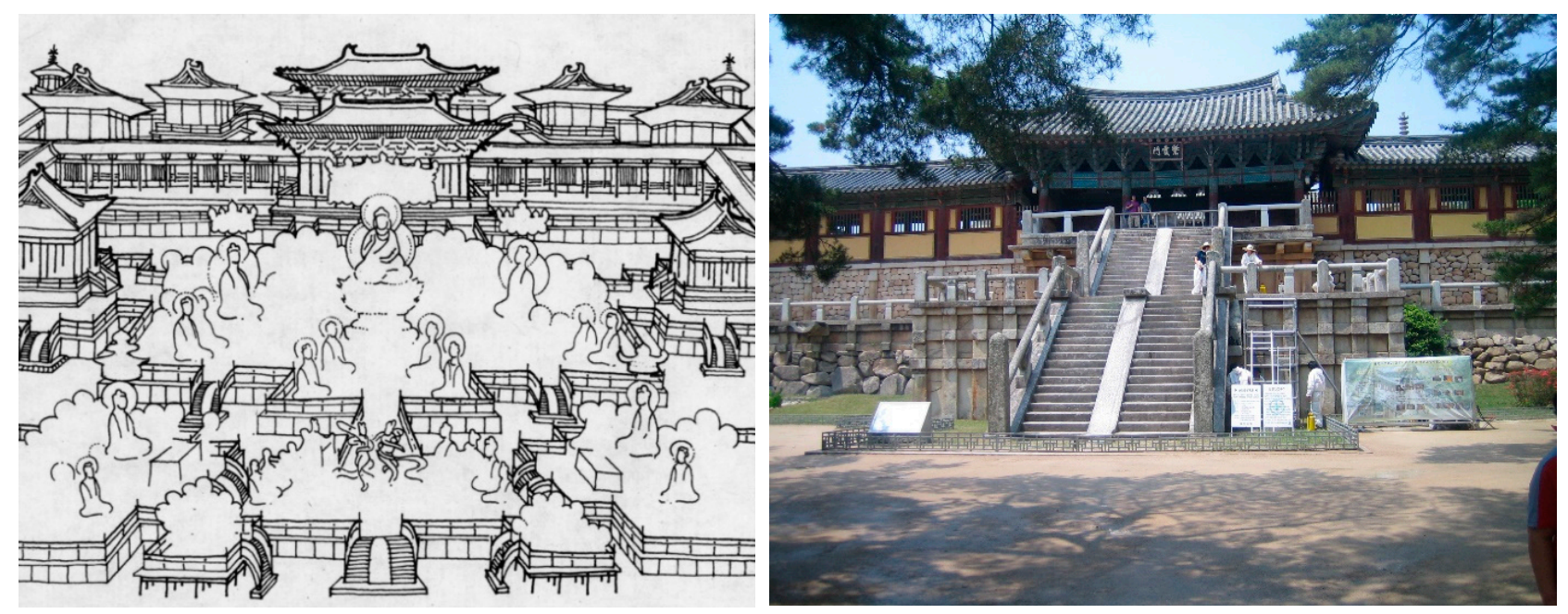

Figure 11. The upper-lower grand terraced platforms with a central stairway at Bulguksa (Right, photo by author) and multi-terraced wooden platform at Dunhuang Cave 148, the Western Amitabha Paradise, Mid Tang (Left, source: Xiao Mo).

Accordingly, the multistory stone platforms of Bulguksa Temple are noteworthy in these respects. The level platforms appear in front of the second flight of stairs where devotees climb a flight of stairs at the first arched bridge. The first-level platform is wider than the others, which have enough room for performance and playing musical instruments. An arched gate was naturally formed underneath the second flight of stairs and second arched bridge. The grand platform was constructed by combining the pile-up structure with the framed one. Capital blocks that are almost square-shaped do not resemble the kind of capital block that supports columns. The outlines show that hidden transverse beams 
and penetrating tie beams exist behind the walls. The stone platform shapes a framework joined by mortises and tenons. It is derived from a Chuandou framework composed of columns and tie beams. Thus, the stone framework results in a pile construction (Figure 12).

Daeungjeon and Geukrakjeon Halls were reconstructed in the 18th century, but their foundation and stairways were built in the first foundation during the eighth century. The buildings were revived in an old location. The distance from the vicinity of the worship stone to the foundation of Daeungjeon Hall is $7.07 \mathrm{~m}$. The distance from the principal image in the Hall to the end of the foundation is $8.45 \mathrm{~m}$. When the two distances are combined, the entire distance from the principal image to the worship stone is $15.52 \mathrm{~m}$ (Figure 13).
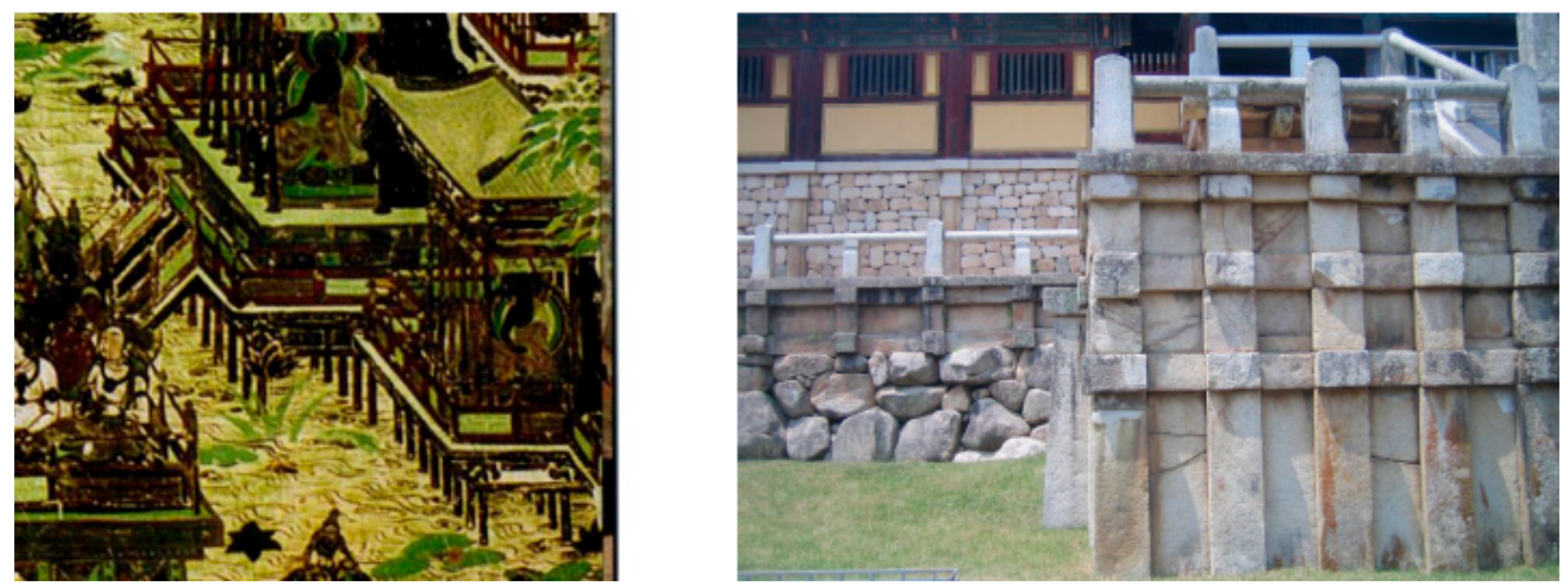

Figure 12. Terraced platforms at Bulguksa Temple and wooden platform with pile construction at Dunhuang Cave 172, the Western Amitabha Paradise, Mid Tang (source: Xiao Mo).

The distance between a worshiper standing in front of the worship stone and the principal image is approximately $15.5 \mathrm{~m}$ (Mitsumori 1999). The current appearance shows that the stone lamp obstructs the devotees' field of vision toward the principal image because it is located in front of the worship stone. This implies that the method of presentday worship is different from that of the Silla era. Unfortunately, although there is no information about daily rituals in the courtyard during the Silla period, other countries have records of their daily activities during the same period. For example, the Nanhaiji guinei fachuan 南海寄歸内法傳 by the monk Yijing (635-713) records, “One sitting down, one's feet touch the ground," and "devotees walk three times around a pagoda, offering incense and flowers. They all kneel down."(Yijing and Takakusu 1970, pp. 123-24). Thus, the rituals were not intended to allow devotees to see the principal image, rather these devotees prayed to images because the process of worship was more significant in the sangha community of the time.

In the case of Daeungjeon Hall, the distance between a devotee and a principal image is approximately $15.5 \mathrm{~m}$, and that between the base stones of the middle gate and the worship stone is $12.7 \mathrm{~m}$. In the case of rain and snow, if devotees worship the principal image from the middle gate, the distance between the principal image and the devotee standing in the middle gate and corridor would be more than $30 \mathrm{~m}$, which is the proper distance to provide a perspective view for extreme concentration and one-way vocal communication during the ritual performance (Hall 1966, pp. 42-43) (Figure 13).

In special cases, it should be considered that worship existed from the middle gate and corridor (including intermediate corridors to connect the main hall and the east-west gates or corridors on both sides), although there was a long distance from the principal image and devotees. In contrast, it is possible to cultivate stupa worship from the corridor and the middle gate. To understand this relationship, a few measurements were performed. In particular, the ratio of the foundation's height of the main hall to that of the two pagodas 
has a significant meaning. The eastern pagoda's foundation is $1.97 \mathrm{~m}$ high, while the main hall's foundation is $1.66 \mathrm{~m}$ high. Their relationship offers an equivalent height hierarchy. When the image's dais is more than approximately $1.6 \mathrm{~m}$ high, the total height from the image dais to the ground level of the main hall is approximately 3.13 meters, which is comparable to those of a lion statue sitting on the foundation of the eastern pagoda and the first story of the western pagoda, $3.28 \mathrm{~m}$ and $3.43 \mathrm{~m}$ each (Table 1).

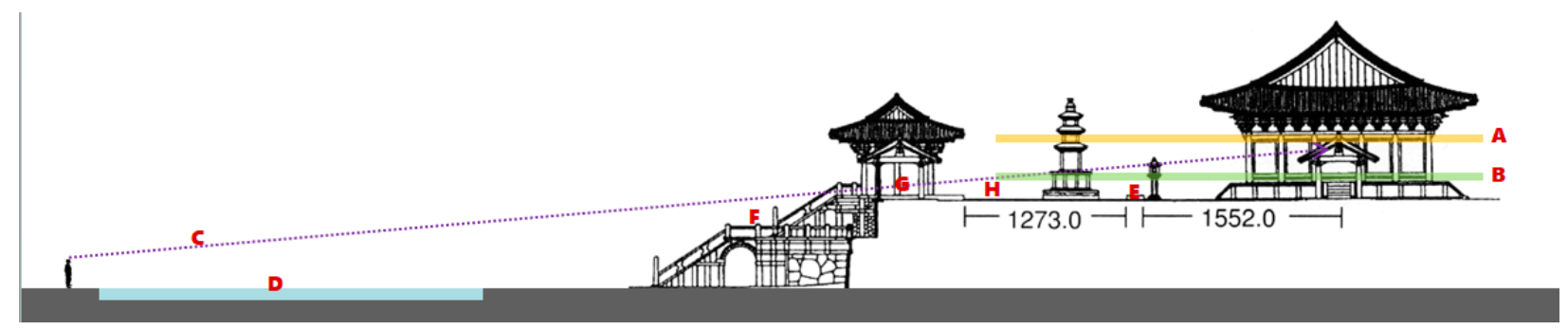

Figure 13. Ritual Concept at Bulguksa Temple (Kim 2011). A: Height of Buddha Image; Location of Sarira Casket; B: Height of the West Pagoda's Foundation; Height of the Main Hall's Foundation; C: Human Angle (10 to 15 degrees) from the Lotus Pool (Nine Ranks for Rebirth); D: Lotus Pool (Pond); E: Worship Stone (Bongnodae); F: Flat Stone Platforms; G: Gate (Jahamun); H: Flat Platform with Enclosure Pure Land.

The western pagoda's foundation is $2.44 \mathrm{~m}$ tall, and the entire height from the image dais to the ground level of the main hall is approximately $3 \mathrm{~m}$. The location of the inner chamber considered is $5.11 \mathrm{~m}$ high. The Buddha image enshrined in the Dauengjeon Hall sits about $1.66 \mathrm{~m}$ high, and the total height from the image to the ground level of the main hall is $4.79 \mathrm{~m}$. In comparison with the location of the inner chamber in the western pagoda standing at $5.11 \mathrm{~m}$, the hierarchical relationship of the buildings is almost in an equivalent position with an error range of $0.31 \mathrm{~m}$. Meanwhile, in the eastern pagoda, the top side of the substructure supporting the pavilion is $4.59 \mathrm{~m}$ high. Moreover, the hierarchical link between the two buildings is almost in a corresponding position with an error range of $0.20 \mathrm{~m}$ (Figure 13, Table 1). The equivalent relationship is applied to other sites in the same period as the monastic buildings at Bulguksa Temple: such a hierarchical approach has something in common with the decisions regarding the building layout of Hwangnyongsa, Sacheonwangsa, Gameunsa, Geodonsa, and Mangdeoksa Buddhist Monasteries. In particular, in Hwangnyongsa Monastery, the image pedestal height corresponds to that of the foundation platform for a wooden pagoda. In the Geodonsa Temple site, the three-story stone pagoda with a three-stepped foundation platform is comparable to an image pedestal in the main hall. The height of the image pedestal was identified with that of a three-stepped foundation platform (Han 2003) (Table 1).

The equivalent hierarchy between the two pagodas and the Daeungjeon Hall in Bulguksa Temple, and other Buddhist sites in the same period or afterward, demonstrates the important notion that devotees regarded the pagodas and the main hall as a total frame. They understood them in a narrative frame that constructs the Buddha's life (Kim 2011).

The miniature shrine (Geumdang) stored in the West Pagoda (Seokgatap) chamber is hierarchically identified with the Buddha image of the main hall, and the horizontal level between the Buddha sculpture and miniature golden hall inside the pagoda needs to be considered to understand the relationship between the two pagodas and the main hall. The Bulguksa seoseoktapjungsu hyeongjigi noted that the western Buddha pagoda stores a golden hall (sarira casket), a gilt-bronze lotus throne, 47 sariras, flavorings, 39 beads, and 15 miniature votive stupas in a heavenly chamber built inside the pagoda's body at the second story in the period of its foundation. Even though the report was written in the early 11th century, the name "Geumdang" represents the symbolic meaning of Buddha's stupas and sarira. The Geumdang Hall's container for placement of the Buddha's sarira indicates that stupas were considered places where the Buddha resides, and sariras were regarded as the living presence of the Buddha. 
There are no records concerning Pure Land rituals in Bulguksa Monastery. However, the records of Pure Land's cults in the ancient Japanese monasteries of Hojoji and Byodoin are comparable to those of Bulguksa in architectural portrayals.

Table 1. Comparison in Height between the Pagoda's Foundation and the Main Hall's Foundation (Measurement unit: meters).

\begin{tabular}{|c|c|c|c|c|}
\hline Height (H) & $\begin{array}{l}\text { Height of the Pagoda's } \\
\text { Foundation: A }\end{array}$ & $\begin{array}{l}\text { Height of the Main } \\
\text { Hall's Foundation: B }\end{array}$ & $\begin{array}{l}\text { Height Difference } \\
\text { between } A \text { and } B\end{array}$ & \\
\hline $\begin{array}{l}\text { Bunhwangsa } \\
\text { 634 CE }\end{array}$ & 1.50 & unknown & unknown & \\
\hline $\begin{array}{c}\text { Hwangnyongsa } \\
645 \mathrm{CE}\end{array}$ & 1.60 & 1.10 & $\begin{array}{c}0.50 \\
(\mathrm{~A} / \mathrm{B}=1.45)\end{array}$ & Buddha dais: 0.5 . \\
\hline $\begin{array}{c}\text { Sacheongwangsa } \\
679 \mathrm{CE}\end{array}$ & 1.50 & 1.15 & $\begin{array}{c}0.35 \\
(\mathrm{~A} / \mathrm{B}=1.30)\end{array}$ & \\
\hline $\begin{array}{l}\text { Gameunsa } \\
682 \mathrm{CE}\end{array}$ & 2.58 & 1.90 & $\begin{array}{c}0.70 \\
(\mathrm{~A} / \mathrm{B}=1.35)\end{array}$ & $\begin{array}{l}\text { Height of underground } \\
\text { channels: } 0.60\end{array}$ \\
\hline $\begin{array}{c}\text { Mangdeoksa } \\
684 \text { CE (or } 679 \text { CE) }\end{array}$ & 1.26 & 0.95 & $\begin{array}{c}0.31 \\
(\mathrm{~A} / \mathrm{B}=1.32)\end{array}$ & \\
\hline $\begin{array}{c}\text { Bulguksa East Pagoda } \\
\text { (EP) } \\
742 \mathrm{CE}\end{array}$ & 1.97 & 1.53 & $\begin{array}{c}0.44 \\
(\mathrm{~A} / \mathrm{B}=1.29)\end{array}$ & $\begin{array}{l}\text { Height(E) to the } \\
\text { platform above column }\end{array}$ \\
\hline $\begin{array}{c}\text { Bulguksa West Pagoda } \\
\text { (WP) } \\
742 \mathrm{CE}\end{array}$ & 2.44 & $\begin{array}{c}\text { Dais (H): } 1.60 \\
\text { Total height: } 4.79\end{array}$ & $\begin{array}{c}0.91 \\
(\mathrm{~A} / \mathrm{B}=1.59)\end{array}$ & $\begin{array}{l}\text { ground level: } 4.59 \\
\text { Height(W) to the } \\
\text { heavenly chamber from } \\
\text { the ground level: } 5.11\end{array}$ \\
\hline
\end{tabular}

\subsection{Monastery Hojoji and Its Buddhist Rituals}

The Hojoji Monastery法成寺was developed in the process of converting Fujiwara Michinaga's 藤原道長 (966-1028) home into a Pure Land monastery on the western bank of the Kamo River in Kyoto (Sugiyama 1981, pp. 87-93; Ota 2010, pp. 149-77, 193-203) (Figure 14). The Eiga Monogatari recorded there describes an entire plan for establishing the monastic complex of Hojoji by superimposing mountains, digging a pond, and planting trees in a row, and for the form of the main buildings, sanctums, and the manner of ornamentation of a golden hall. The Amitabha hall has a tile-roof facing east, which is flanked by subsidiary buildings, such as pavilions, attached to long corridors on both sides. All doors were covered in golden leaves. The Yakushi Hall was built on the western side of the link with the Amitabha hall, in terms of the form and ornament of the building; i.e., the hall was identified with the appearance of the Amitabha hall (Matsumura and Yutaka 1965, pp. 152-54; Shimizu 1986a, 1986b).

According to Eiga Monogatari, a lotus pond in front of the Amitabha hall was fully completed on 22 March 1020. Laypeople enjoyed boating in the pond during the ritual, while carrying a carriage. All buildings (east, west, north, and south), including a belfry and sutra tower, forming shadows on the pond. The landscape provided the appearance of 3000 worlds (Matsumura and Yutaka 1965, pp. 445-46; Minamoto 1965). All halls were designed with gold leaf ornaments that cast shadows on the pond. This implies that all building locations were close to the lotus pond. The layout of Hojoji was intended to represent the 3000 worlds in mutual associations with all the shrine's halls and ponds. To ensure the visual effect of the pond's siting, the landscape around the pond was considered with several points in mind: sand flashed like a crystal, water from the pond became clear and pure, and a Buddhist image floated in harmony with the multicolored lotus flower. Buddha halls in the north, south, east, and west, a sutra tower, and a belfry tower were 
projected onto the pond. Treasure trees were used to hang the multicolored fishing nets along the pond. A bridge was decorated with seven treasures and ships were embellished with various treasures. There were imitations of a peacock and a pelican parrot on the central island. In addition, during a 10,000-lamp festival that took place around the pond on 10 March 1023, treasure trees were erected, and artificial multicolored lotus flowers and Buddha images were floated in the pond (Matsumura and Yutaka 1965, pp. 108-10; Shimizu 1986a). During the performance of the ritual, the combination of the buildings, the pond with shadows cast in the daylight, and the lights at night provided an important visual effect and presented an unusual scene, different from the mundane world. The landscape produced an impressive state, like a pure land.

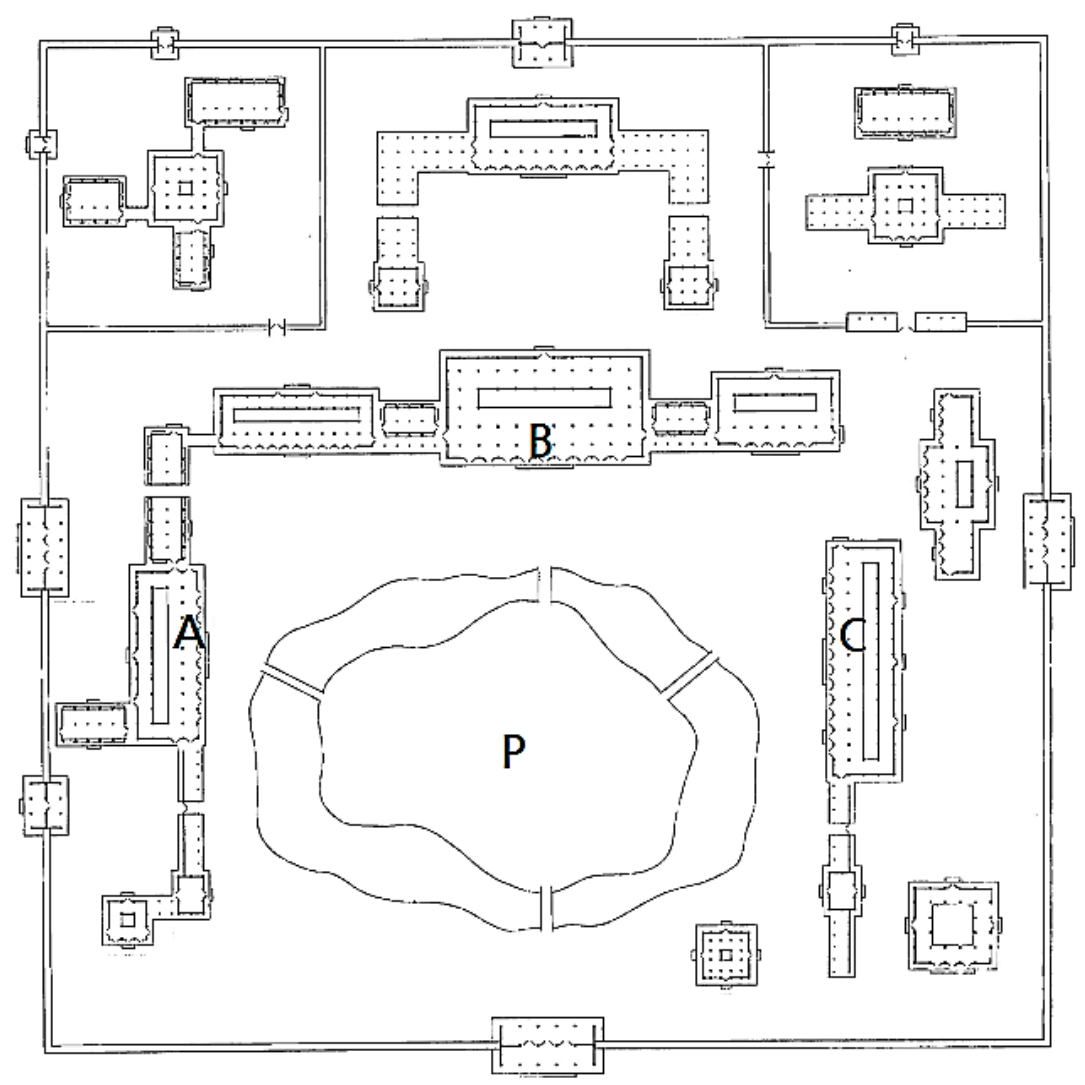

Figure 14. The first construction of the Monastery Hojoji. P: A platform for rituals on an island, a lotus pond, C: Yakushi Hall, A: Amitabha Hall, B: Main Hall.

\subsection{Byodoin Monastery and its Buddhist Rituals}

The Phoenix Hall, Hoodo, and Amidado are situated on the western bank of the Uji River in the scenic town of Uji, not far from the ancient Heian capital, Kyoto. The Phoenix Hall at Byodoin 平等院 consists of a central hall to enshrine an image of Amitabha, with intermediate corridors to its left and right, and a rear corridor extending behind it. The rear corridor is seven bays long by one bay wide. The central hall does not have narrow aisles around the core sanctum of Hoodo, and a roof enclosure is directly added to the main building. The hall was built on the central island (Nakashima) at Byodoin (Tatara et al. 1998).

The Byodoin precinct is situated along the Uji River (Figure 15) and has been regarded as the Pure Land. On 4 March 1053, an offering service for the Phoenix Hall was held according to the Fuso Ryakki 扶桑略記. In the record at the time of this memorial service, "Yorimichi built Byodo-in. A tall Buddhist statue $4.6 \mathrm{~m}$ high was enshrined therein." (Koen [1169] 1965; Ota 1988, pp. 94-112). Concerning the performance of the offering, there are no records about the location where visitors were seated and how long dances and music were performed during the cult-although information about the dance and music was 
reported in the Bugaku yoroku 舞楽要録 (Hanawa 1951). However, during a memorial service for a new pagoda on 25 October 1061, Sadaie asonki 定家朝臣記, another piece of text stated that there was an inner altar on a long couch that was extremely splendid and utterly beautiful. There were 20 seats for the devotees. Under the floors of the building, there were other seats for consecration ceremonies installed on the southeast, northeast, northwest, and southwest corners of the new pagoda. Along narrow aisles and corridors, there were seats for the visitors. The use of the aisles and corridors was akin to the example of the Hojoji Monastery (Kurokawa and Tsunoda 1969; Ota 1988, pp. 94-112).
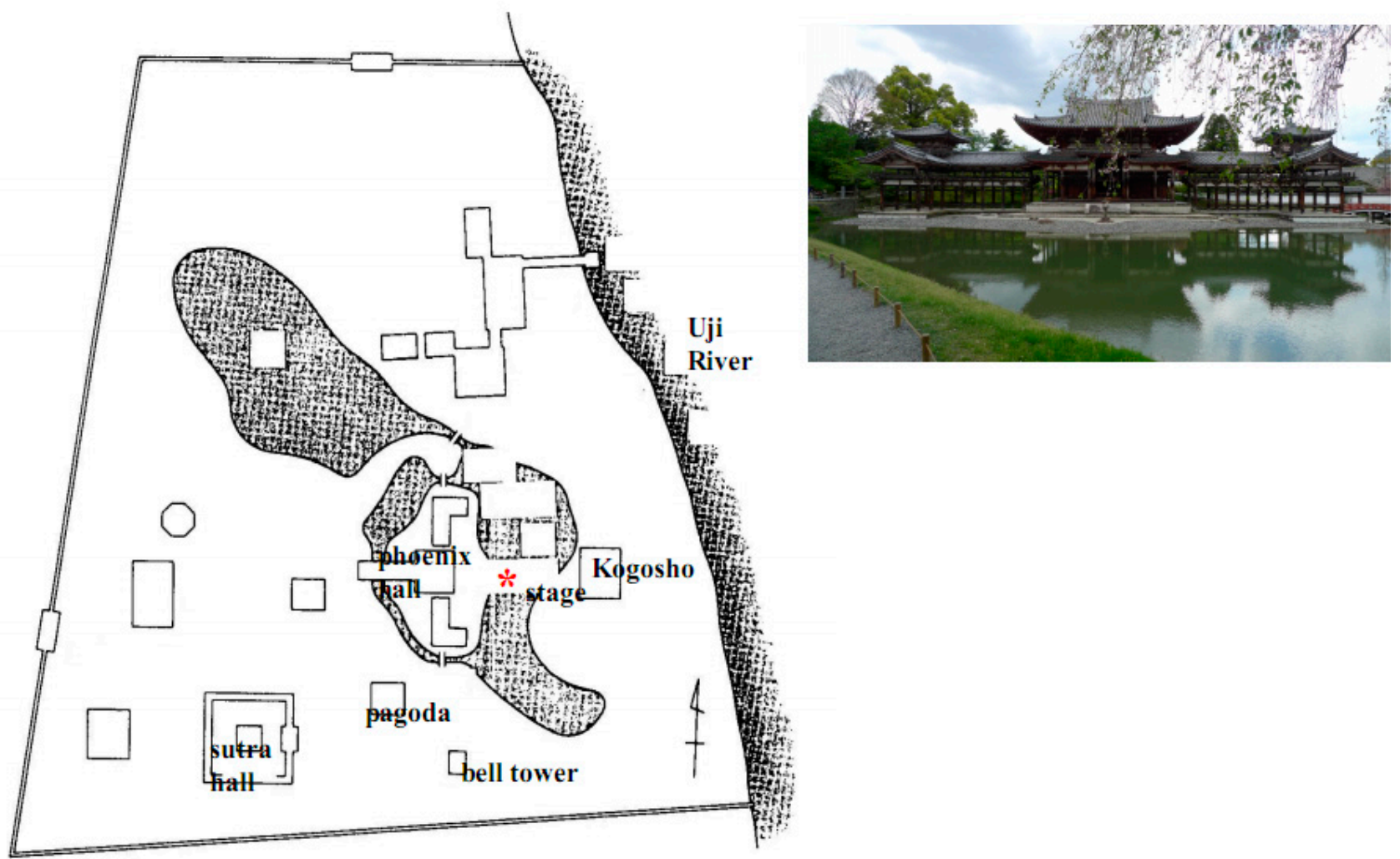

Figure 15. Byodo-in, the Phoenix Hall and Little Imperial Palace (Kogosho).

On 25 October 1061, the garden site and Amitabha hall were described as unusual and outstanding in the Fuso Ryakki, and a sukhavati was also represented. The text added that the Phoenix Hall was "conducive to meditative reflection on sukhavati" Moreover, the Uji River is considered part of the long river previously covered with reeds which leads groups to a world representing the highest complete understanding of truth, currently 'gone to the beyond' (Koen [1169] 1965). They speak to the psychological condition of the visitors who reached the Byodoin Monastery, utilizing the Uji River from the Heian capital.

Chuyuki, on 21 September in 1118, explained 10 kinds of memorial services performed by Fujiwara Yorimichi, reporting "lotus, waterfowls, trees, sand-made swans, and so on were made and then installed to float on the pond, and the hill of the water no longer had any space. The Kogosho 小御所 (Little Imperial Palace) in the eastern side was for an empress dowager, and the Saiin 斎院 was an imperial palace for a daughter of empress dowager. Some women served the imperial palace. A temporary house with four bays stood for high-ranking officials on the western side, and the one facing the eastern aisle was used for visitors at Byodoin Monastery, and tent structures were established in the eastern garden."(Fujiwara 1965). The text states that Kogosho was located on the eastern bank of the lake across the Amitabha hall. The palace was situated at a vantage point so that the rituals could be observed. It was also the place where Yorimichi and his heirs gathered to observe the garden. The text also implies that there was a stage in the pond in front of the 
Amitabha hall, and the entire territory around the pond was filled with imitations, such as flowers and waterfowls. In addition, boats might float on the pond to create a stage (Motonaka 1994, p. 250).

\subsection{Re-Interpreting Buddhist Rituals at Bulguksa Temple}

As seen in the votive events at Hojoji and Byodoin Monasteries, Bulguksa Monastery created similar spectacles during the Pure Land cults along with the grand terraced platforms and around the Yeonji Lotus Pond on the ground. The Jahamun (golden purple) and Anyangmun (peace enhancing) gates, stairways with banisters, and four bridges are situated on the terraced stone platforms at Bulguksa. The main platform with balustrades is located in front of the Lotus Pond measuring $39.5 \mathrm{~m}$ from east to west and $25.5 \mathrm{~m}$ from north to south. The second-storyed platform with balustrades has a stage on which dances and music were played during a ritual (Munhwagongbobu 1976, pp. 63, 69). Additionally, a small arched gate on the second-storied platform might be used for circumambulation rituals. The devotees marched in procession toward two Buddha pagodas through two worship stones and two stone lanterns, and the Buddha Hall at the end. The processions might also appear along a narrow path with balustrades installed on the open terraced platform, via a square-shaped stage on the second platform and cloud-shaped pillars of Beomyeongnu (Figures 16 and 17).

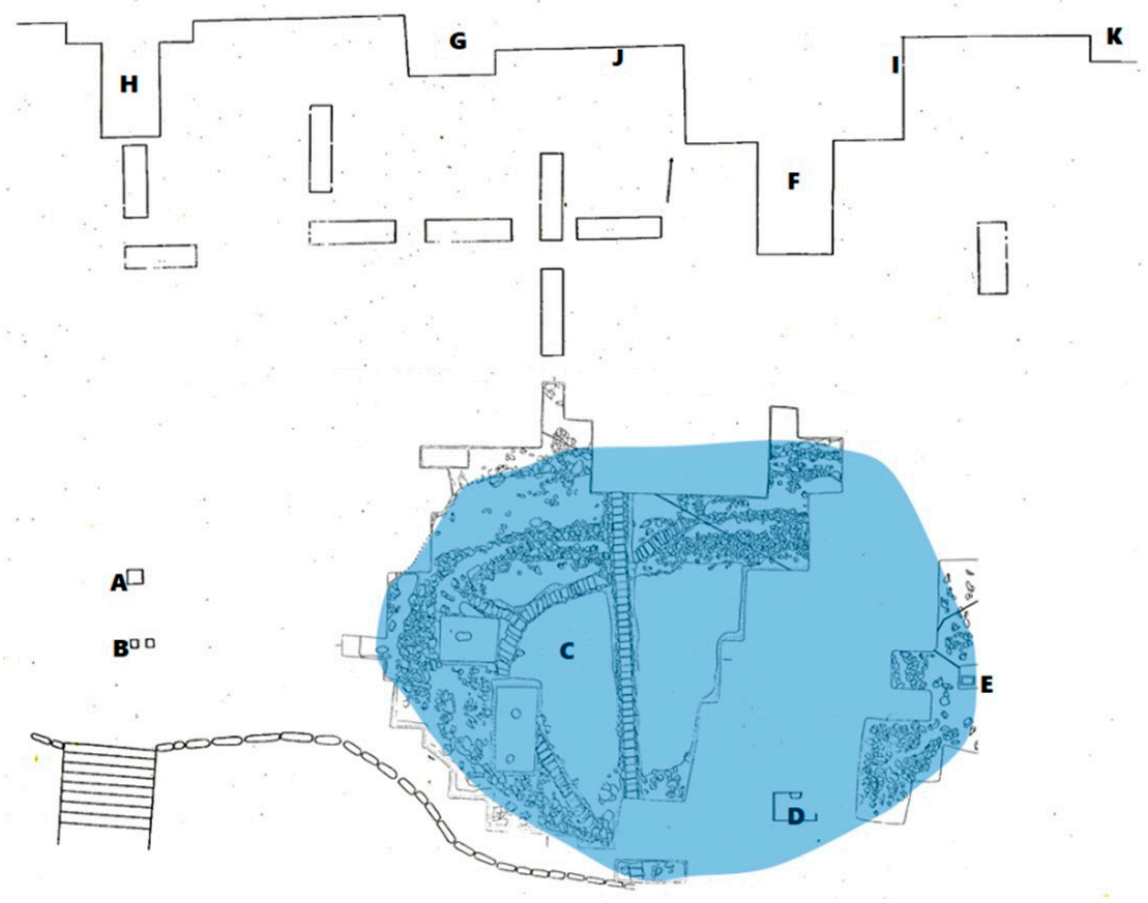

Figure 16. The Archeological Findings of Lotus Pool and Surrounding Building Configuration (Kim 2011). A: flagpole support, B: Sarira Stupa, C: Lotus Pool, D: Previous Main Gate, E: Bulguksa Stele, F: Cheongungyo and Baekungyo Bridges, G: Beomyeongnu (Ugyeongnu) Pavilion, H: Yeonhwagyo and Chilbogyo Bridges, I: Multi-storied Grand Stone Platforms, J: Pathways of Grand Stone Platforms, K: Jwagyeongnu Pavilion. 


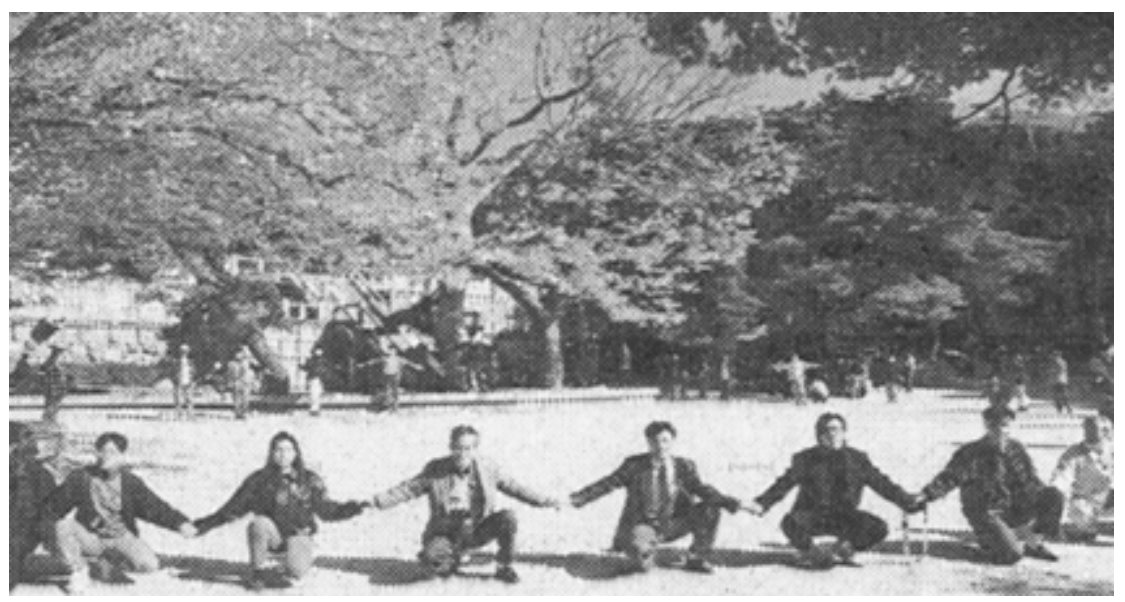

Figure 17. The territory of Lotus Pool represented by researchers in front of Baekungyo Bridge (Gyoeonghyang Sinmun, 8 November 1994).

Likewise, donors who stood in open-roofed corridors watched the spectacles that happened in a lotus pool of nine ranks for posthumous rebirth. This indicates that the symbolic organization of the nine levels or three types of rebirth was easily accepted by ruling clans to common persons in Silla society. The open roofed corridors are located in two places: on platforms with balustrades to an east-west axis, and in the inner courtyard. The roofed corridors open without any wooden-framed walls in the two photos of the Sekino Tadashi archive, although they are closed between the main courtyards and stone platforms at present (Tokyoteikokudaigaku Kokadaigaku 1904; Gukgagirokwon 1918-1924) (Figures 18 and 19). In addition, the remains of several buildings were found on the western side under the grand-terraced platforms (Figure 2). The buildings might be associated with the lotus pond on the east-west axis, as Kogosho was located at a vantage point to watch the rituals on the east-west axis with the Amitabha hall.

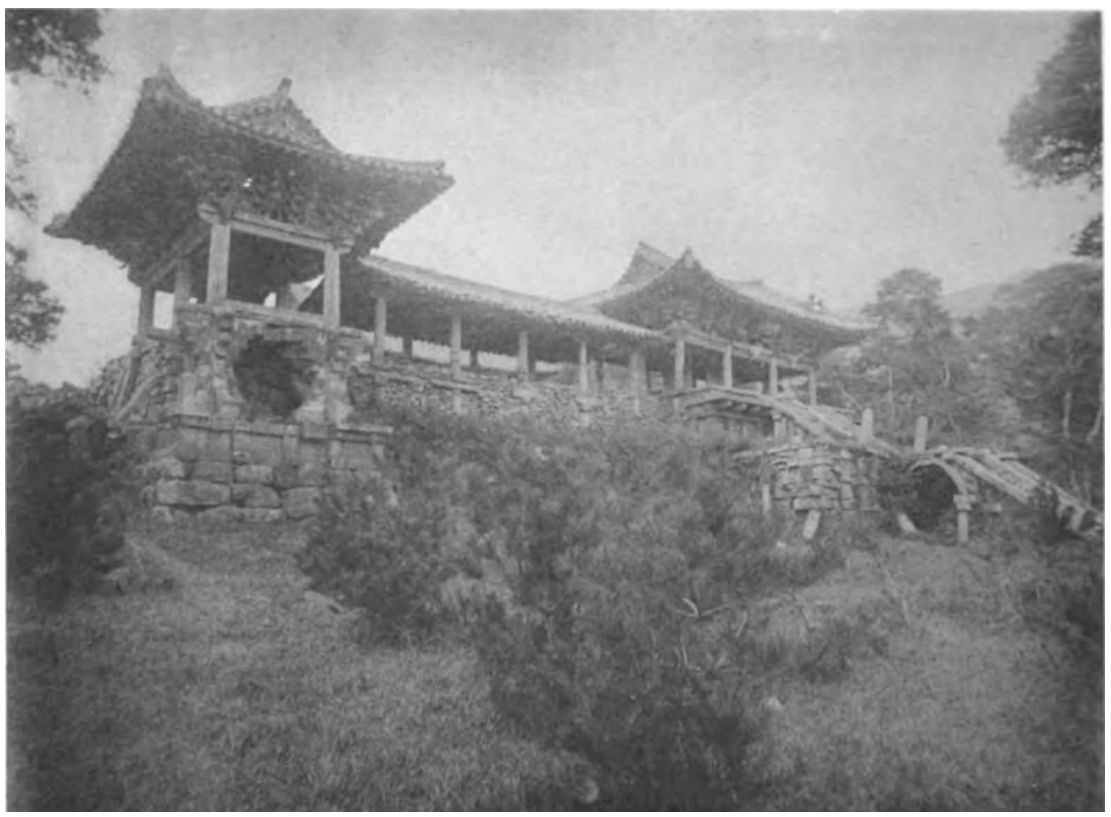

Figure 18. Sekino's photo on the Bulguksa Monastery's Front Buildings (Tokyoteikokudaigaku Kokadaigaku 1904). 


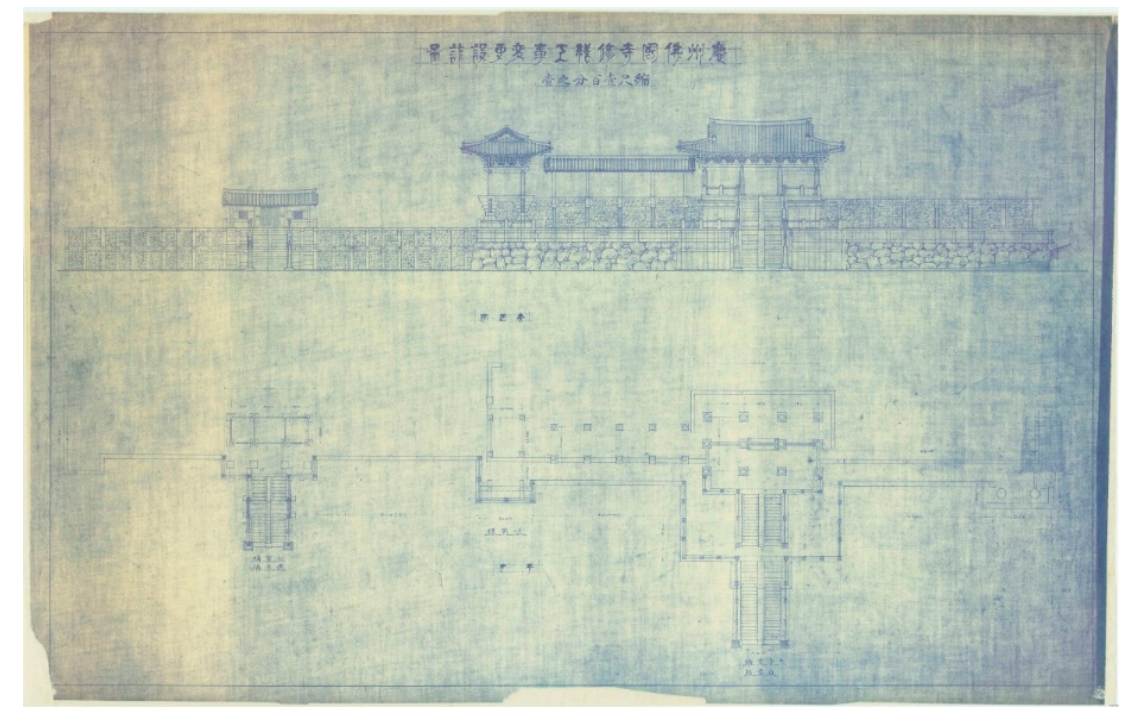

Figure 19. Restoration Plan (a line drawing between 1918 and 1924) on the basis of Sekino's photo (Gukgagirokwon).

In the past, the pond at Bulguksa might be filled with numerous imitations of lotuses, waterfowls, trees, and swans made of paper or sand during the festival, compared to the appearance of the lotus pool in the transformation tableaux of monastery caves. In particular, the Pure Land murals at Dunhuang Caves 217 and 172 in High-Tang consist of three buildings on a level platform at the center of the painting (Figures 9 and 10). The front central hall has five bays, like the Daeungjeon Hall at Bulguksa Monastery, and the wider central bay of the front building resembles the central bay of Daeungjeon Hall. The mural composition focuses on the lotus pool in front of the main hall using a one-point perspective method. This sense of perspective occurs through the difference in the distance between the lotus pool and buildings. The former is located in front of the devotees, while the latter is located far away from them.

Similarly, the application of the elevated vantage point appears in Bulguksa architecture. An impressive perspective appears in the combination of the lotus pond and elevated grand platform with main buildings situated at a very long distance. The elevated platforms maximize a sense of perspective and emphasize the Pure Land surrounded by splendid buildings spread over a long distance. When Pure Land cults take place on the lotus pool or around it, devotees look at the grand-terraced platform and buildings seen through the open-roofed corridors. The positions on which devotees stand around the lotus pool make it possible for them to feel a sense of awe toward the Pure Land. Such application of the elevated vantage point indicates that the Pure Land is far away from the secular world. The intended spatial depth in the central group of buildings on the elevated platforms is the result of embracing the devotees in the paradisiac atmosphere. Such an atmosphere makes the devotees feel the bliss of the Pure Land (Figures 13 and 16).

\section{Conclusions}

The early concepts of the Pure Land as "sukhavati" in the Chinese translation, such as the "anle" and "jile," which signify "extreme happiness," become more concrete and powerful through images for visualization and meditation rituals, in the mixture of a supernatural transcendent being in Taoism with a chakravartin king in Buddhism.

Furthermore, the Pure Lands as the abodes of miscellaneous deities correspond to the lands of Taoist hermits in their quest for immortality, and the cosmic order that symbolizes the authority of rulers. Images of paradise appear in the buildings (e.g., platforms, pile-built constructions called "galan," high-rise pavilions, pagodas), landscape (e.g., mountains, clouds, ponds), and simultaneously through the architectural representation of Buddhist temples. 
Together with these ceremonial constructions, the rituals and samadhi practice towards the Pure Land served as powerful tools to dignify and strengthen the Buddha Land's position. Cults and practices as tools controlled the behavior of laypeople and monks. They satisfied their psychological and emotional needs in the law of dependent origination (Pratityasamutpada) between buildings and devotees.

The Monastery Bulguksa is a ritual apparatus. The architectural representation of a Pure Land that subsumes lotus ponds, courtyards, and open terraced platforms with banisters as stages for dancers and musicians is further emphasized. It provides an application of the elevated vantage point from a perspective and focuses on ritualized practices associated with meditation and votive events linked to pure land ceremonies.

As a result, based on Buddhist narratives, such framed story structures of the Pure Land continue to produce an integrated and pure world far away from the secular one, and toward the sacred places of key events in the Buddha's life.

Funding: This research was supported by Basic Science Research Program through the National Research Foundation of Korea (NRF) funded by the Ministry of Education (No.2021R111A3059811).

Conflicts of Interest: The authors declare no conflict of interest.

\section{Notes}

1 Four significant scriptures related with the Pure land tradition follow the Wuliang qingjing pingdengjue jing (Taisho12, no 361), the Foshuo amituo sanye sanfosalou guodu rendao jing (Taisho12, no 362), the Larger Sukhavati vyuha sutra (Taisho 12, no 360), and the Amitayurdhyana sutra (Taisho12, no 365). These Pure Land-related scriptures were translated from the Sanskrit version into the classical Chinese version, which influenced the establishment of Pure Land architecture in East Asia. These documents will be dealt with in detail in Section 5.1 .

2 The Pure Land is interpreted as follows: Skt. Buddhaksetra; Ch. shatu, fotu, foguotu, foshentu; Kor. ch'altu, bulto, bulgukto, pulsint'o. The Pure Land is also translated into "jingtu" and "jile" for Sinification. It implies that the real world had been part of the existence of the living Buddha specifically in terms of sacred sites associated with key events in the Buddha's life story; these places became important for traveling to get the merit (Bharati 1963, pp. 135-36).

3 The author referred to Tsukamoto's two books. Tsukamoto re-organized the afore-mentioned inscriptions of other sites in India, including those of Nagarjunakonda sites (site 5 and site 43), and then compiled all Indian Buddhist inscriptions which were translated by Vogel, Sircar, Sarkar, Narasimha, Rama, Shizutani, and Sadakata. The first version of Nagarjunakonda inscriptions translated to English can be identified in Vogel's works. (Vogel 1929-1930; Sircar 1963-1964; Tsukamoto 1986, Tsukamoto 1996-1998; Rama 1967; Shizutani 1979; Sadakata 1994).

4 In particular, the well preserved text came from ayaka-pillar B5 (one of five pillars usually erected on the four cardinal directions), namely the fifth pillar on the south side of the great Buddhist Stupa at Site 1, Nagarjunakonda. This noted the gift of a stone pillar by the Mahadevi(Queen) Rudradharabhatarika, King Siri-Virapurisadata's daughter from Ujjeni (Skt. Ujjayini), while the Mahachetiya (great stupa) was raised by the ladies, the Mahatalavaris, Chamtisitinika of (the family of) the Pukiyas. (Vogel 1929-1930, p. 19).

5 Nagarjuna wrote, “through proper honoring of stupas, you will become a Universal Monarch. Your glorious hands and feet marked with (a design of) wheels. Through the practices there are fame and happiness here, there is no fear now or at the point of death, in the next life happiness flourishes, therefore always observe the practices." (Nagarjuna, Taisho 32 no 1656) Thus, we should note that the welfare and happiness of the entire world mean both the present world and posthumous future world as labeled on the inscriptions. Devotees at Nagarjunakonda and other areas have dreamt of the representation of the Pure Land or heavenly world in the real world from early Buddhist time. These epigraphical and literary proofs indicate that in ages past the monuments were crucial instruments for obtaining merit-transferring and merit-making devotees, and ultimately, for fulfilling Pure Land architecture.

6 The Amitabha not only means "measureless light," but also "measureless wisdom." In the Chinese translation, the jingtu, jile, and qingjing have a similar context. They refer to a pure, a no-ado, and an anle pleasure place, or an ideal nirvana.

7 The "qingjing" is similar in meaning to the "anle" and "jingtu," which are frequently used in the Wuliangshoujing lun and Tan Luan's Wuliangshoujing lunzhu. The term "jingtu" representing Amitabha's religion is derived from the name of the Buddha in the Pingdeng juejing and Wuliang qingjing.

8 It was expressed in the text of the Ratnavali and the inscriptions of Nagarjunakonda (Walser 2005).

9 Afterwards, the ritual method was consistently followed by descendent monks. Xuanzang, a Tang monk, mediated upon the Bodhisattva Maitreya. He turned all his thoughts to the Heaven of the blessed one, praying ardently that he might be reborn there to pay homage to the Bodhisattva. His boat was once attacked by pirates who attempted to kill him as a sacrificial offering to the ferocious Sivaite goddess Durga, while a Silla monk, Wonhyo, proposed "there are three grades for people to cultivate the 
visualization, and the highest grades of people are those who either cultivate the Samadhi of Buddha visualization or repentance as their method of practice. In their present body, they will succeed in seeing Maitreya. According to the quality of their mind, the image they see will either be great or small." (Sponberg and Hardacre 1988, pp. 94-95; Kitagawa 1988).

Lokasema's translated texts in the second-century state the Buddha of the Ten Directions, "if one's heart is focused on Amitabha one will be reborn in sukhavati, the Western Pure Land presided over by Amitabha." Additionally, Huiyuan established a Buddhist center at Lushan, Jiangxi, and another at Xiangyang, Hubei. He described a miraculous sculpture at Xiangyang and a painting of the "shadow" or "reflection" of the Buddha (foyingxiang) at Lushan. The statue and picture might be related to meditation or visualization practices in the locales.

11 When Tanjie fell seriously ill, Daoan chanted continuously, the name of Maitreya Buddha never leaving his lips. Zhisheng (Taoan's disciple), who waited on him in his illness, asked him why he did not want to be reborn in the Heaven of Peaceful Response (i.e., Amitabha's paradise, sukhavati). Tanjie replied, "Together with the Reverend (Daoan) and eight others, I have vowed to be reborn in Tusita (i.e., Maitreya's paradise). The Reverend, Daoan, and the others have already been born there, but I have not. That is why I have this wish" (Kieschnick 1997, p. 5).

“Dae Hwaeom Bulguksa birojanabulmun munsu bohyeon bosal chanbyeongseo is listed in the Bulguksa gogum changgi佛國寺古今歷代記. The conquests of Asoka were realized through the imperial ideas of India. Through his strong espousal of the sangha communities, as well as the construction of 84,000 stupas all over the Jambudvipa, he was both a transformative body of the Buddha and a cakravartin (Strong 1989, p. 117). The cakravartin legends became an archetypal example of the Buddhist kingship, and were spread among several hagiographical works. for the repair works of the nine-story pagoda of Hwangnyongsa in the Silla period. The inscription writes, "Hitherto (The construction of the pagoda) has led to the peaceful and happy life of sovereign and subject 君臣安樂至今賴之.” As in the Hwangnyongsagucheungmoktap chaljubongi 皇龍寺九層木塔刹柱本記. in the 11th year (871) of Silla King Gyeongmun, the repair work began on a nine-story wooden pagoda at Hwangryongsa Monastery. In this process, Park Geo-Mul recorded the construction of the wooden Buddhist pagoda and repair process from 871 (the 11th regnal year of King Gyeongdeok) to 872 CE.

15 Korean Buddhism did not show political upheavals and heavily depended on the personal preferences of rulers, while at least four anti-Buddhist campaigns occurred in China in 446 (Northern Wei), 557 (Northern Zhou), 845 (Tang), and 955 (Later Zhou) in the contemporaneous period.

16 See the Gamsansa Seokjomireukbosaripsang Josanggi 甘山寺石造爾勒菩薩立像造像記. The inscription consists of 21 rows and 391 characters, which have been left on these images. The Taoist idea shows a teaching about the various disciplines for achieving "perfection" by becoming one with the unplanned rhythms of the universe called "the way" or "Tao," in association with the faith of ancient East Asians who desired to become hermits in mountains or tall buildings after death (Gamsansa Seokjomireukbosaripsang Josanggi 720).

17 Recently, some scholars have argued that the completion of the main territory of a Buddha hall and Buddha pagodas had already been done before $742 \mathrm{CE}$, as determined by epigraphical evidence such as Bulguksa mugujeonggwangtap jungsugi 佛國寺無垢淨光 塔重修記 (Bulguksa Mugujeonggwangtopjoongsugi 1024) and Bulguksa seoseoktap jungsu hyeongjigi 佛國寺西石塔重修形止記 (Bulguksa Seoseoktapjungsuhyeongjigi 1038).

18 Kim Daeseong and his father, Kim Munryang, of Samgukyusai, and Kim Daejeong and Kim Munryang of Samguksagi are the same person. Kim Munryang served as Prime Minister from 706-711 under King Seongdeok, and Kim Dae jeong served as King Gyeongdeok from 745-750.

19 Bulguksa mugujeonggwangtap jungsugi, Bulguksa seoseok-tap jungsu hyeongjigi, and Bulguksa jungsu bosimyeong gongjungsomyoeonggi show that the original names of the pagodas were not Tathagata Prabutaratna and Tathagata Sakyamuni Pagodas at the time of the first construction. (Cheon 1996).

20 The larger Sukhavativyuha sutra (The Sutra on the Buddha of Eternal Life), translated from the Sanskrit by F. Max Mueller, edited by Richard St. Clair. Available on: https:/ /www.nanputuo.com/npten/html/201203/2816073173499.html (accessed on 10 June 2021).

21 In order to make an argument about historic shifts in style at Dunhuang, I utilize the reference scheme developed by the Dunhuang Research Academy. The number within the parentheses pertains to the number of caves allocated in the following periods: early-Tang 618-704 (40), high-Tang 705-80 (81), mid-Tang 781-847 (46), late-Tang 848-906 (60), Five Dynasties 907-59, Song 960-1035, and Western Xia (Xi xia) 1036-1226 (Xiao 1989, p. 30).

22 In particular, the lotus pond is a reminder of the "nine levels of rebirth" in the Amitayurdhyana sutra or the "three types of persons to be reborn" in the Larger Sukhavati vyuha sutra. 


\section{References \\ Primary Sources}

Larger Sukhavati Vyuha Sutra 佛説無量壽經. Taisho 12, no. 360.

Wuliang Qingjingpingdengjuejing 無量清淨平等覺經. Taisho 12, no. 361,

Foshuo Amituo Sanye Sanfosalou Guodu Rendao Jing 佛説阿彌陀三耶三佛薩樓佛檀過度人道經. Taisho 12, no. 362.

Amitayurdhyana Sutra 佛説觀無量壽佛經. Taisho 12, no. 365.

Amitayurdhyana Sutra (Smaller Sukhavati vyuha sutra) 佛説阿彌陀經. Taisho 12, no. 366.

Pratyupannasamadhi Sutra Banzhou Sanmei Jing 般舟三昧經. Taisho 13, no. 418

Suvarnaprabhasa sutra 金光明經 (Golden Light Sutra). Taisho 16, no. 663.

Guannian Amituofo Xiangbai Sanmei Gonde Famen Jing 觀念阿彌陀佛相海三昧功德法門 (Meritorious Methods of Contemplating Amitäbha Buddha). Taisho 47, no. 1959.

Saddharmapundarika妙法蓮華經 (Lotus Sutra). Taisho 9 no 262.

Nagarjuna, Paramārtha. Ratnavali 寶行王正論(Precious Garland), Taisho 32 no 1656.

Dae Hwaeomjong Bulguksa Birojana Munsu Boheon Bosal Chanbyeongseo 大華嚴宗佛國寺毘盧遮那文殊普賢像讚扭序.

(Gamsansa Seokjomireukbosaripsang Josanggi 720) Gamsansa Seokjomireukbosaripsang Josanggi, 720，甘山寺石造彌勒菩薩立像造像記 (the Dedicatory Inscriptions (Josanggi) on the Amitabha Buddha and the Maitreya Bodhisattva statues of Gamsansa Temple).

(Ilyeon 1281) Ilyeon, Samguk Yusa. 1281. 三國遺事 (Memorabilia of the Three Kingdoms).

(Kim 1145) Kim, Busik. 1145. Samguk Sagi 三國史記 (History of the Three Kingdoms).

(Hwaram Doeun 1740) Hwaram Doeun. 1740. Bulguksa Gogeum Changgi 佛國寺古今創記 (Architectural History of Bulguksa).

(Beopgyedogi Chongsurok 1254) Beopgyedogi Chongsurok. 1254. 法界圖記叢隨錄 (Collected Essentials of Records on the Dharma Diagram).

(Koen [1169] 1965) Koen, Katsumi Kuroita. 1965. Fuso Ryakki Teio Hennenki 扶桑略記 帝王編年記. Tokyo: Yoshikawa Kobunkan. First published 1169.

(Matsumura and Yutaka 1965) Matsumura, Hiroji, and Yutaka Yamanaka. 1965. Eiga Monogatari榮花物語. Nippon koten bungaku taikei 76, Tokyo: Iwanami Shoten, a story from 1028 to 1107.

(Fujiwara 1965) Fujiwara, Munetada. 1965. Chuyuki中右記, Zoho Shiryo Taisei Kankokai, Kyoto: Rinsen Shoten, Fujiwara's diary written from 1087 to 1138 .

(Bulguksa Jungsubosimyeong Gongjungsomyoeonggi 1038) Bulguksa Jungsubosimyeong Gongjungsomyoeonggi. 1038. 佛國寺塔重修布施名公衆僧小名記 (Document on the Name of Almsgiving from Laypeople and Monks of Bulguksa).

(Bulguksa Mugujeonggwangtopjoongsugi 1024) Bulguksa Mugujeonggwangtopjoongsugi. 1024. 佛國寺無垢淨光塔重修記 (Repair Report of Rasmivimalavisuddhaprabhadharani Cetiya (Endless Untainted Light Pagoda) of Bulguksa Monastery).

(Bulguksa Seoseoktapjungsuhyeongjigi 1038) Bulguksa Seoseoktapjungsuhyeongjigi. 1038. 佛國寺西石塔重修形止記 (Repair Report of the West Stone Pagoda of Bulguksa Monastery).

(Hwanglyongsa Gucheungmogtab Geumdongchaljubongi 871) Hwanglyongsa Gucheungmogtab Geumdongchaljubongi 皇龍寺九層木塔刹柱本記. 871. (Basic Annals concerning the Pillar of the Nine-story Pagoda of Hwangnyong-sa).

(Gukgagirokwon 1918-1924) Gukgagirokwon 1918-1924, Restoration Plans of Monastery Bulguksa, Gukgagirokwon(National Archive of Korea).

Anonymous, n.d. Western Paradise of the Buddha Amitabha(Northern Qi dynasty, 550-577), Freer Gallery of Art, Smithsonian Institution, Washington, DC. Available online: https:/ / asia.si.edu/object/F1921.2/ (accessed on 26 June 2021).

\section{Secondary Sources}

Apte, Vaman Shivaram. 1957-1959. A Revised and Enlarged Edition of Prin. V. S. Apte's The Practical Sanskrit-English Dictionary. Poona: Prasad Prakashan, vol. 3.

Bharati, Agehananda. 1963. Pilgrimage in the Indian Tradition. History of Religions 3: 135-67. [CrossRef]

Chappell, David W. 1977. Chinese Buddhist Interpretations of the Pure Lands. In Buddhist and Taoist Studies I. Edited by Michael Saso and David Chappell. Honolulu: University Press of Hawaii.

Cheon, Haebong. 1996. Mugujeonggwangdaranigyeong 無垢淨光大陀羅尼經, Hanguk Minjok Munhwa Daebaekgwasajeon. Available online: http:/ / encykorea.aks.ac.kr/Contents/Item/E0018943 (accessed on 20 August 2021).

Corless, Roger J. 1982. T'an-Luan: Taoist Sage and Buddhist Bodhisattva. Buddhist and Taoist Practice in Medieval Chinese Society. Edited by David W. Chappell. Buddhist and Taoist Studies 2. Honolulu: University of Hawaii Press, pp. 36-45.

Fujita, Kotatsu. 1970. Genshi Jodo Shiso No Kenkyu. Tokyo: Iwanami Shoten, pp. 141-61.

Hall, Edward Twitchell. 1966. The Hidden Dimension. New York: Doubleday.

Han, Jeongho. 2003. Silla seoktabui ijunggidan balsaengwonine daehan gochal (The Origination Cause of Double Deck Foundation of the Silla Stone Pagodas). Silla Munhwa-je Haksul Balpyohoe Nonmunjib 24: 61-96.

Hanawa, Hokiichi. 1951. Zoku Gunshoruiju. Tokyo: Zoku Gunshoruiju Kanseikai, vol. 19.

Hay, John. 1999. Questions of influence in Chinese art history. Res: Anthropology and Aesthetics 35: 240-62. [CrossRef] 
Ho, Poay-Peng. 1995. Paradise on earth: Architectural depiction in pure land illustrations of high Tang caves at Dunhuang. Oriental Art 41: 22-32.

Iwamoto, Yutaka. 1978. Bukkyo Setsuwa no Densho to Shinko. Tokyo: Kaimei Shoin, pp. 57-79.

Katsuki, Genichiro. 1992. Tonko Mogaoku dai 220ku amida joudohenzo zu ko. Bukkyo Geijutsu 202: 67-92.

Kieschnick, John. 1997. The Eminent Monk: Buddhist Ideals in Medieval Chinese Hagiography. Honolulu: University of Hawaii Press.

Kim, Young Jae. 2011. Architectural Representation of the Pure Land: Constructing the Cosmopolitan Temple Complex From Nagarjunakonda to Bulguksa. Ph.D. dissertation, University of Pennsylvania, Philadelphia, PA, USA.

Kim, Young Jae. 2018. The Origin and Development of the Pavilion at the Contact Points of the East and the West-Between Asia Minor and Indian Subcontinent. The Eastern Art 38: 34-61. [CrossRef]

Kitagawa, Joseph M. 1988. “The Many Faces of Maitreya". In Maitreya, the Future Buddha. Cambridge: Cambridge University Press, pp. $7-22$.

Kurokawa, Harumura, and Bun'ei Tsunoda. 1969. Sadaie ason ki, Rekidai Zanketsu Nikki. Kyōto-shi: Rinsen Shoten.

Li, Baijin. 2007. Tang Fengjian Zhuyingzao. Beijing: Zhongguo Jianzhu Gongye Chubanshe.

Macdonell, Arthur Anthony. 1929. A Practical Sanskrit Dictionary with Transliteration, Accentuation, and Etymological Analysis Throughout. London: Oxford University Press.

Mair, Victor H. 1986. Records of Transformation Tableaux (pienhsiang). T'oung Pao 72: 3-43. [CrossRef]

Minamoto, Tsuneyori. 1965. Sakeiki 左経記, Zoho ShiryoTaisei Kankokai 6. Kyoto: Rinsen Shoten.

Mitsumori, Masashi. 1999. Kodai bukkyou jiin no reihai kuukan to reihai seki. In Bukkyo Bijutsu No Kenkyu. Kyoto: Jishosha, pp. $185-212$.

Mizuno, Seichi, and Nagahiro Toshio. 1941. Kanan Rakuyo Ryumon Sekkutsu No Kenkyu (Longmen Caves' Study in Luoyang, Henan). Tokyo: Zauho kankoka.

Motonaka, Makoto. 1994. Nippon Kodai No Teien to Keikan. Tokyo: Yoshikawako Bunkan.

Munhwagongbobu, Munhwajaegwalliguk. 1976. Bulguksa Bokwongongsa bogoseo (Restoration Work Report of Bulguksa). Gyeongju: Gyeongju City Government.

Nakamura, Hajime. 1975. Jodo Kyoten no Seiritsu Nendai to Chiiki. In Jodo Sanbukyo. Tokyo: Iwanami Shoten.

Ota, Hirotaro. 1988. Byodo-in Taikan: Dai 1 Kan Kenchiku. Tokyo: Iwanami Shoten.

Ota, Seiroku. 2010. Shindenzukuri No Kenkyu. Shinsoban. Tokyo: Yoshikawa Kobunkan, pp. 149-77, $193-203$.

Pas, Julian. 1987. Dimensions in the Life and Thought of Shan-tao(613-681). In Buddhist and Taoist Practice in Medieval Chinese Society. Edited by David W. Chappell. Honolulu: University of Hawaii, University of Hawaii Press, pp. 65-84.

Pyyhtinen, Olli. 2014. The Gift and Its Paradoxes: Beyond Mauss. Farnham: Ashgate Publishing, Ltd.

Rama, Rao. 1967. Inscriptions of the Andhradesa. 2 vols. Sri Venkatesvara University Historical Series, No. 5. Tirupati: Sri Venkatesvara University.

Sadakata, Akira. 1994. Tōkai Daigaku kiyō Bungakubu 61 (Bulletin of the Faculty of Literature of Tokai University). Available online: https: / / searchworks.stanford.edu/view / 4227370 (accessed on 10 June 2021).

Shimizu, Hiroshi. 1986a. Hojo-ji no garan to sono seikaku. Nippon Kenchiku Gakkai Keikaku Kei Ronbun Houkoku Shu 363: $158-67$.

Shimizu, Hiroshi. 1986b. Byodo-in no garan to sono seikaku. Tokyokougei Daigaku Kougakubu Kiyou 8: 65-72.

Shizutani, Masao. 1979. Indo Bukkyō Himei Mokuroku (Catalog of Indian Buddha Monument Inscription). Kyōto: Heirakuji Shoten.

Sircar, D. C. 1963-1964. More Inscriptions from Nagrjunakonda. Epigraphia Indica XXXV: 1-36.

Sponberg, Alan, and Helen Hardacre, eds. 1988. Maitreya, the Future Buddha. Cambridge and New York: Cambridge University Press. Sugiyama, Shinzo. 1981. Inka Kenchiku No Kenkyu. Tokyo: Yoshikawa Machi Koubun Kan.

Tatara, Miharu, Andreas Hamacher, and Shirai Hikoe. 1998. Jodo teien no kuukan kousei nikansuru kousatsu: Hojo-ji oyobi Byodo-in o jirei toshite (Consideration on the spatial composition of the Pure Land Garden: Hojoji Temple and Byodoin Temple). Chiba Daigaku Engei Gakubu Gakujutsu Houkoku 52: 33-42.

Tokyoteikokudaigaku Kokadaigaku. 1904. Kankoku kenchiku chōsa hōkoku韓國建築調査報告 (Research Report of Korean Architecture). Tokyo: Tokyo Teikoku Daigaku.

Tsukamoto, Keisho. 1986. Hokekyo No Seiritsu to Haikei: Indo Bunka to Daijo Bukkyo 法華経の成立と背景: インド文化と大乗仏教 (Formation and the Background of the Lotus Sutra: Indian Culture and Mahayanist Buddhism). Tokyo: Kosei.

Tsukamoto, Keisho. 1996-1998. Indo Bukkyo Himei no kenkyu インド仏教碑銘の研究(The Study of the Buddhism Epigraph). 2 vols. Kyoto: Heirakuji.

Vogel, J. P. 1929-1930. No. 1 Prakrit Inscriptions from a Buddhist Site at Nagarjunikonda. In Epigraphia Indica, XX ed. Hiranand Shastri and New Delhi: Archaeological Survey of India, pp. 1-37.

Walser, Joseph. 2005. Nagarjuna in Context: Mahayana Buddhism and Early Indian Culture. Columbia: Columbia University Press.

Wong, Dorothy C. 1998. Four Sichuan Buddhist Steles and the Beginnings of Pure Land Imagery in China. Archives of Asian Art 51: 56-79.

Wong, Dorothy C. 2008. The Mapping of Sacred Space Images of Buddhist Cosmographies in Medieval China. In The Journey of Maps and Images on the Silk Road. Edited by Andreas Kaplony and Philippe Foret. Leiden: E. J. Brill, pp. 66-95.

Wright, Arthur. 1948. Fo-t'u-teng, a Biography. Harvard Journal of Asiatic Studies 11: 321-71. [CrossRef] 
Wu, Hung. 1992a. Reborn in Paradise: A Case Study of Dunhuang Sutra Painting and its Religious, Ritual and Artistic Context. Orientations 23: 55-56.

Wu, Hung. 1992b. What is Bianxiang? On the Relationship between Dunhuang Art and Dunhuang Literature. Harvard Journal of Asiatic Studies 52: 111-92.

Xiao, Mo. 1989. Dunhuang Jianzhu Yanjiu (Research on Dunhuang Architecture). Beijing: Wenwu Chubanshe.

Xu, Chaohua. 1987. Er Ya Jin Zhu 爾雅今注. Tianjin: Nan Kai Da Xue Chu Ban She.

Yijing, I.-Tsing, and J. Takakusu. 1970. A Record of the Buddhist Religion as Practiced in India and the Malay Archipelago. Oxford: The Clarendon Press.

Zürcher, Erik. 1959. The Buddhist Conquest of China. Leiden: E. J. Brill. 